\title{
Myoglobin Post-Translational Modifications Influence Color Stability of Beef Longissimus Lumborum
}

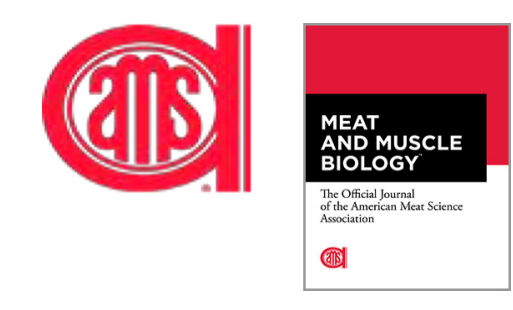

\author{
Yifei Wang ${ }^{1}$, Shuting $\mathrm{Li}^{1}$, Gregg Rentfrow ${ }^{1}$, Jing $\mathrm{Chen}^{2}$, Haining $\mathrm{Zhu}^{2}$, and \\ Surendranath P. Suman ${ }^{1 *}$ \\ ${ }^{1}$ Department of Animal and Food Sciences, University of Kentucky, Lexington, KY 40546, USA \\ ${ }^{2}$ Proteomics Core Facility, University of Kentucky, Lexington, KY 40506, USA \\ *Corresponding author. Email: spsuma2@uky.edu (Surendranath P. Suman)
}

\begin{abstract}
Post-translational modifications (PTM) of proteins play critical roles in biological processes. PTM of muscle proteins influence meat quality. Nonetheless, myoglobin (Mb) PTM and their impact on fresh beef color stability have not been characterized yet. Therefore, our objectives were to identify Mb PTM in beef longissimus lumborum muscle during postmortem aging and to characterize their influence on color stability. The longissimus lumborum muscles from $9(n=9)$ beef carcasses ( $24 \mathrm{~h}$ postmortem) were subjected to wet aging for $0,7,14$, and $21 \mathrm{~d}$. At the end of each wet-aging period, steaks were fabricated. One steak for analyses of PTM was immediately frozen at $-80^{\circ} \mathrm{C}$, whereas other steaks were assigned to refrigerated storage in the darkness under aerobic packaging. Instrumental color and biochemical attributes were evaluated on day 0,3 , or 6 of storage. Mb PTM were analyzed using two-dimensional electrophoresis and tandem mass spectrometry. Surface redness ( $a^{*}$ value), color stability, and $\mathrm{Mb}$ concentration decreased $(P<0.05)$ upon aging. Gel image analyses identified $6 \mathrm{Mb}$ spots with similar molecular weight $(17 \mathrm{kDa})$ but different isoelectric $\mathrm{pH}$. Tandem mass spectrometry identified multiple PTM (phosphorylation, methylation, carboxymethylation, acetylation, and 4-hydroxynonenal alkylation) in these 6 isoforms. The amino acids susceptible to phosphorylation were serine (S), threonine (T), and tyrosine, whereas other PTM were detected in lysine (K), arginine (R), and histidine residues. Additionally, distal histidine (position 64), critical to heme stability, was found to be alkylated. Overall, Mb PTM increased with aging. The aginginduced PTM, especially those occurring close to hydrophobic heme pocket, could disrupt Mb tertiary structure, influence heme affinity, and compromise oxygen binding capacity, leading to decreased color stability of fresh beef. Furthermore, PTM at K45, K47, and K87 were unique to Mb from non-aged beef, whereas PTM at R31, T51, K96, K98, S121, R139, and $\mathrm{K} 147$ were unique to $\mathrm{Mb}$ from aged counterparts, indicating that these $\mathrm{Mb}$ PTM could be used as novel biomarkers for fresh beef color stability.
\end{abstract}

Key words: aging, beef color stability, longissimus lumborum, myoglobin, post-translational modifications Meat and Muscle Biology 5(1): 15, 1-21 (2021) doi:10.22175/mmb.11689

Accepted 21 January 2021

\section{Introduction}

The color of fresh beef is critical to meat industry because it is a major quality attribute influencing consumers' purchasing decisions at the point of sale (Suman et al., 2014). Consumers often use the cherryred color as an indicator of the wholesomeness of fresh meats (Faustman and Cassens, 1990; Mancini and Hunt, 2005; Suman et al., 2014; Neethling et al., 2017). Meat discoloration results in consumer rejection, leading to huge economic loss. The U.S. beef industry incurs an annual revenue loss of $\$ 1$ billion as a result of discoloration (Smith et al., 2000). Myoglobin (Mb) is the sarcoplasmic heme protein responsible for meat color. The concentration and redox forms of $\mathrm{Mb}$ determine the fresh meat color. Furthermore, the primary structure of $\mathrm{Mb}$ dictates its tertiary structure and, in turn, influences its functional properties as an oxygen carrier and its interactions with biomolecules, ultimately affecting meat color (Faustman et al., 2010; Suman and Joseph, 2013; Ramanathan et al., 2020a, 2020b). 
Post-translational modifications (PTM) are covalent changes in proteins by the addition or removal of modifying group(s) at one or more amino acids in the primary structure (Lodish, 1981; Han and Martinage, 1992; Mann and Jensen, 2003). PTM can modulate proteins' functionality, localization, turnover, and interactions with other proteins (Seo and Lee, 2004; Rakhit et al., 2014; Müller, 2017). Previous investigations have documented that PTM in calpain (Liu et al., 2016; Du et al., 2019), myofibrillar proteins (Huang et al., 2012; Li et al., 2017), and metabolic enzymes (Anderson et al., 2014; Cruzen et al., 2015; Carlson et al., 2017; Huang et al., 2018; Liu et al., 2018) in skeletal muscles of livestock (cattle, pig, and sheep) influenced meat tenderness and muscle to meat conversion. The aforementioned studies suggested the potential of protein PTM as novel biomarkers for meat quality (Li et al., 2021).

PTM such as oxidation (Bostelaar et al., 2016; Lindsay et al., 2016), methylation (Santucci et al., 1993), carboxymethylation (Ray and Gurd, 1967; Harris and Hill, 1969), phosphorylation (Stewart et al., 2004; Hojlund et al., 2009; Hohenester et al., 2013), and acetylation (Livingston et al., 1985) influenced the functionality of mammalian $\mathrm{Mb}$. Additionally, alkylation (nucleophilic adduction by reactive aldehydes) compromises stability of beef $\mathrm{Mb}$ (Alderton et al., 2003; Suman et al., 2006, 2007; Yin et al., 2011; Elroy et al., 2015; Viana et al., 2020).

$\mathrm{Mb}$ interacts reciprocally with small biomolecules, proteins, and cellular components in the muscle food matrix during postmortem aging (Richards, 2013; Ramanathan et al., 2020a, 2020b). The biomolecular interactions in postmortem skeletal muscles govern Mb chemistry and color of fresh meats (Fox, 1966; Giddings, 1977; Livingston and Brown, 1981; Seideman et al., 1984; Renerre, 1990; Faustman et al., 2010; Suman and Nair, 2017). Logically, in situ PTM in $\mathrm{Mb}$ can impact fresh meat color stability through modulating the heme protein's structural and functional properties as well as interactions with other biomolecules (Suman and Joseph, 2013).

Recent investigations (Li et al., 2018a, 2018b) identified phosphorylation in glycolytic enzymes and $\mathrm{Mb}$ in sheep longissimus muscle and suggested that phosphorylation might be involved in meat color stability. Nonetheless, in situ PTM in beef Mb and their impact on fresh beef color stability have not been characterized yet. Therefore, the objective of the current study was to characterize the Mb PTM in beef longissimus lumborum (LL) muscle during postmortem aging and their influence on fresh beef color stability.

\section{Materials and Methods}

\section{Beef fabrication}

Beef carcasses ( $n=9$; USDA Choice; A maturity; black-hided crossbred heifers) were obtained from the USDA-inspected meat laboratory at the University of Kentucky (Lexington, KY). LL muscles from the right side of carcasses were removed and divided into 4 equal-length sections after $24 \mathrm{~h}$ postmortem. The muscle sections were vacuum packaged (99\% vacuum; Sipromac Model 600A; Drummondville, Quebec, Canada) in Prime Source vacuum pouches (3 mil, Bunzl Koch Supplies Inc., Kansas City, MO) and randomly assigned to wet aging at $2^{\circ} \mathrm{C}$ for either $0,7,14$, or $21 \mathrm{~d}$. At the end of each wet-aging period, the muscle sections were removed from the vacuum package and fabricated into four 1.92-cm-thick steaks. One steak from each muscle section allotted for proteome analyses was immediately vacuum packaged and frozen at $-80^{\circ} \mathrm{C}$ until used. The remaining 3 steaks were allotted to refrigerated storage for evaluation of the color traits. The 3 steaks utilized for color evaluation were individually placed on Styrofoam trays and aerobically overwrapped with oxygen-permeable film $(15,500$ $16,275 \mathrm{~cm}^{3} / \mathrm{m}^{2} / 24 \mathrm{~h}$ oxygen transmission rate at $23^{\circ}$ C). Packages were randomly assigned for refrigerated storage $\left(2^{\circ} \mathrm{C}\right)$ for either 0,3 , or $6 \mathrm{~d}$ in the darkness (Mancini et al., 2009; Nair et al., 2018a, 2018b). At each storage time point, $\mathrm{Mb}$ concentration, meat $\mathrm{pH}$, instrumental color, metmyoglobin reducing activity (MRA), and lipid oxidation were evaluated.

\section{Instrumental color}

The surface color of steaks was measured instrumentally at each time point using a HunterLab LabScan XE colorimeter (Hunter Associations Laboratory, Reston, VA) with 2.54-cm-diameter aperture, illuminant A, and $10^{\circ}$ standard observer. The colorimeter was calibrated with standard black and white plates. On day 0 of storage, the oxygen-permeable film was removed from the packages, and the steaks were bloomed for $2 \mathrm{~h}$ at $2^{\circ} \mathrm{C}$ before the instrumental color attributes were evaluated. CIE (1976) $L^{*}$ (lightness), $a^{*}$ (redness), and $b^{*}$ (yellowness) values were measured at 6 random locations on the oxygen-exposed surface of each steak (American Meat Science Association, 2012). Additionally, the reflectance was measured from 700 to $400 \mathrm{~nm}$, and the ratio of reflectance at $630 \mathrm{~nm}$ and $580 \mathrm{~nm}$ (R630/580) was obtained as an indirect estimate of surface color stability (American Meat Science Association, 2012). 


\section{Meat $p H$}

The $\mathrm{pH}$ value of raw steak samples was determined according to the method of Strange et al. (1977). Triplicate 5-g muscle samples were homogenized with $25 \mathrm{~mL}$ of distilled deionized water (at $25^{\circ} \mathrm{C}$ ), and the $\mathrm{pH}$ was measured utilizing an Accumet AR25 pH meter (Fisher Scientific, Pittsburg, PA).

\section{Lipid oxidation}

Lipid oxidation was measured using the thiobarbituric acid assay (Yin et al., 1993). Triplicate 5-g of sample - from the surface and interiors of the steaks - was homogenized with $22.5 \mathrm{~mL}$ of $11 \%$ trichloroacetic acid solution and filtered through Whatman No. 1 paper (GE Healthcare, Little Chalfont, UK). One milliliter of aqueous filtrate was mixed with $1 \mathrm{~mL}$ of aqueous thiobarbituric acid and incubated at $25^{\circ} \mathrm{C}$ for $20 \mathrm{~h}$. The absorbance values at $532 \mathrm{~nm}$ were measured utilizing a UV-2401PC spectrophotometer (Shimadzu Inc., Columbia, MD) and were presented as thiobarbituric acid reactive substances (TBARS).

\section{Metmyoglobin reducing activity}

MRA was measured at 3 time points (day 0,3, and 6) of each aging period. MRA was evaluated according to Sammel et al. (2002). Triplicate $2.45-\mathrm{cm}$ samples removed from the oxygen-exposed steak surface were submerged in $0.3 \%$ sodium nitrate (Sigma-Aldrich Co., St. Louis, MO) solution for $20 \mathrm{~min}$ at room temperature to facilitate metmyoglobin formation. After 20 min, the samples were removed from the solution, blotted dry, and vacuum packaged. The reflectance spectra were measured from 700 to $400 \mathrm{~nm}$ on the lightexposed surface using a HunterLab LabScan XE colorimeter immediately after vacuum packaging in order to calculate pre-incubation surface metmyoglobin values (American Meat Science Association, 2012). The samples were then incubated at $30^{\circ} \mathrm{C}$ for $2 \mathrm{~h}$ allowing for metmyoglobin reduction, and then surface reflectance was rescanned to calculate post-incubation metmyoglobin values (American Meat Science Association, 2012). MRA was calculated using the following equation:

$$
\begin{aligned}
\text { MRA }= & 100 \times[(\% \text { pre-incubation surface metmyoglobin } \\
& -\% \text { post-incubation surface metmyoglobin }) \\
& / \% \text { pre-incubation surface metmyoglobin }] .
\end{aligned}
$$

\section{Myoglobin concentration}

The $\mathrm{Mb}$ concentration was measured at 3 time points (day 0, 3, and 6) of each aging period.
Triplicate 5-g samples were homogenized with $45 \mathrm{~mL}$ ice-cold $40 \mathrm{mM}$ sodium phosphate buffer at $\mathrm{pH} 6.8$ (Faustman and Phillips, 2001). The homogenate was filtered through Whatman No. 1 paper, and the absorbance of the filtrate was measured at $525 \mathrm{~nm}\left(\mathrm{~A}_{525}\right)$ utilizing a UV-2401PC spectrophotometer (Shimadzu Inc., Columbia, MD) with $40 \mathrm{mM}$ sodium phosphate buffer as a blank. The $\mathrm{Mb}$ concentration was calculated using the following equation:

$$
\begin{aligned}
\mathrm{Mb}(\mathrm{mg} / \mathrm{g})= & {\left[\mathrm{A}_{525} /\left(7.6 \mathrm{mM}^{-1} \mathrm{~cm}^{-1} \times 1 \mathrm{~cm}\right)\right] } \\
& \times(17,000 / 1,000) \times 10
\end{aligned}
$$

where $7.6 \mathrm{mM}^{-1} \mathrm{~cm}^{-1}=\mathrm{mM}$ absorptivity coefficient of $\mathrm{Mb}$ at $525 \mathrm{~nm} ; 1 \mathrm{~cm}=$ light path length of cuvette; $17,000 \mathrm{Da}=$ average molecular weight of $\mathrm{Mb}$; and $10=$ dilution factor.

\section{Isolation of sarcoplasmic proteome}

The sarcoplasmic proteomes from samples $(n=9)$ frozen $\left(-80^{\circ} \mathrm{C}\right)$ on each of the aging days $(0,7,14$, and 21) were extracted according to the method of Joseph et al. (2012). Frozen samples were thawed overnight at $2^{\circ} \mathrm{C}$. Five grams of muscle tissue devoid of any visible fat and connective tissue was homogenized in $25 \mathrm{~mL}$ of ice-cold extraction buffer ( $40 \mathrm{mM}$ Tris, $5 \mathrm{mM}$ ethylenediaminetetraacetic acid [pH 8]) using a Waring blender (Model No. 51BL32; Waring Commercial, Torrington, CT). The homogenate was then centrifuged at $10,000 \times g$ for $15 \mathrm{~min}$ at $4^{\circ} \mathrm{C}$. The supernatant consisting of sarcoplasmic proteome extract was filtered through Whatman No. 1 paper (GE Healthcare) and used for subsequent analyses (Joseph et al., 2012; Nair et al., 2018a, 2018b).

\section{Two-dimensional electrophoresis}

The protein concentration of the sarcoplasmic proteome extract was determined in duplicate employing the Bradford assay (Bradford, 1976) utilizing the Bio-Rad Protein Assay kit (Bio-Rad Laboratories Inc., Hercules, CA). Nine hundred micrograms of sarcoplasmic proteome was mixed with rehydration buffer (Bio-Rad Laboratories Inc.) optimized to $7 \mathrm{M}$ urea, $2 \mathrm{M}$ thiourea, $20 \mathrm{mM}$ dithiothreitol, 4\% 3-[(3-cholamidopropyl)dimethylammonio]-1-propanesulfonate, $0.5 \%$ Bio-Lyte 5/8 ampholyte and $0.001 \%$ Bromophenol blue. The mixture of sarcoplasmic protein and rehydration buffer was loaded into immobilized $\mathrm{pH}$ gradient strips (pH 5-8; $17 \mathrm{~cm}$; Bio-Rad Laboratories Inc.) and subjected to passive rehydration for $16 \mathrm{~h}$ (Joseph et al., 2012). First-dimension isoelectric focusing, 
which enables the separation of proteins based on their isoelectric point ( $\mathrm{pI}$ ), was performed using a Protean isoelectric focusing cell system (Bio-Rad Laboratories Inc.). A low voltage $(50 \mathrm{~V})$ was applied during the initial active rehydration for $4 \mathrm{~h}$, followed by a linear increase in voltage, and a final rapid voltage ramping to attain a total of $60 \mathrm{kVh}$. Following this, the immobilized $\mathrm{pH}$ gradient strips were equilibrated with equilibration buffer I (6 M urea, $0.375 \mathrm{M}$ Tris- $\mathrm{HCl}$ [pH 8.8], $2 \%$ sodium dodecyl sulfate [SDS], 20\% glycerol, and $2 \%[\mathrm{w} / \mathrm{v}]$ dithiothreitol; Bio-Rad Laboratories Inc.) followed by equilibration buffer II (6 M urea, $0.375 \mathrm{M}$ Tris- $\mathrm{HCl}$ [pH 8.8], 2\% SDS, 20\% glycerol, and 2.5\% [w/v] iodoacetamide), each for $15 \mathrm{~min}$. Second-dimension separation of protein was achieved by $13.5 \%$ SDSpolyacrylamide gel electrophoresis (38.5:1 ratio of acrylamide to bis-acrylamide) in a Protean II Multicell system (Bio-Rad Laboratories Inc.). The equilibrated strips were loaded onto $18.5 \mathrm{~cm} \times 20 \mathrm{~cm}$ lab cast SDS-polyacrylamide gel electrophoresis gels with an agarose overlay, and the electrophoresis was completed using running buffer ( $25 \mathrm{mM}$ Tris, $192 \mathrm{mM}$ glycine, $0.1 \%$ SDS) at room temperature. A constant voltage of $100 \mathrm{~V}$ was applied for approximately $16 \mathrm{~h}$ to allow the separation of proteins in the second dimension. Beef LL muscle during the aging days $(0,7,14$, and 21) from all the carcasses $(n=9)$ was analyzed in duplicate, resulting in a total of 72 gels.

\section{Gel staining and image analyses}

Gels were stained for phosphorylated protein using Pro-Q Diamond (Invitrogen, Carlsbad, CA) according to manufacturer recommendations. Gels were immersed in fixing solution $(50 \%$ methanol and $10 \%$ acetic acid) and incubated twice at room temperature with gentle agitation for $30 \mathrm{~min}$. Fixed gels were then immersed in ultrapure water in order to remove all the methanol and acetic acid. Pro-Q Diamond phosphoprotein gel stain was used to stain the gels for $2 \mathrm{~h}$ in the dark, followed by destaining in destaining solution ( $20 \%$ acetonitrile, $50 \mathrm{mM}$ sodium acetate [pH 4]) for 30 min 3 times. Gels were washed with ultrapure water 2 times before they were imaged (532 nm laser; excitation: $555 \mathrm{~nm}$; emission: $580 \mathrm{~nm}$ ) using a TyphoonTM FLA 9500 biomolecular imager (GE Healthcare). After gel imaging, gels were stained with Sypro Ruby Protein gel stain (Invitrogen, Carlsbad, CA) overnight in the dark and were transferred to a clean container, where they were destained twice with destaining solution (10\% methanol, $7 \%$ acetic acid) for $30 \mathrm{~min}$ and rinsed with ultrapure water. Gels were then imaged $(473 \mathrm{~nm}$ laser; excitation: $450 \mathrm{~nm}$; emission: $610 \mathrm{~nm}$ ) utilizing a TyphoonTM FLA 9500 biomolecular imager (GE Healthcare). Gel images stained with Pro-Q Diamond and Sypro Ruby were analyzed using PDQUEST software (Bio-Rad Laboratories Inc.).

\section{Liquid chromatography-electrospray ionization-tandem mass spectrometry}

The protein gel spots with similar molecular weight of $17 \mathrm{kDa}$ were excised and subjected to dithiothreitol reduction, iodoacetamide alkylation, and in-gel trypsin digestion using a standard protocol (Shevchenko et al., 2006). The resulting tryptic peptides were extracted, concentrated, and subjected to shot-gun proteomics analysis as previously described in Kamelgarn et al. (2018). Nano-liquid chromatography (LC)-tandem mass spectrometry (MS/MS) analysis was performed using an LTQ-Orbitrap mass spectrometer (Thermo Fisher Scientific, Waltham, MA) coupled with an Eksigent Nanoflex cHiPLC system (Eksigent, Dublin, CA) through a nano-electrospray ionization source. The peptide samples were separated with a reversedphase cHiPLC column $(75 \mu \mathrm{m} \times 150 \mathrm{~mm})$ at a flow rate of $300 \mathrm{~nL} / \mathrm{min}$. Mobile phase A was water with $0.1 \%(\mathrm{v} / \mathrm{v})$ formic acid, whereas B was acetonitrile with $0.1 \%(\mathrm{v} / \mathrm{v})$ formic acid. A 50-min gradient condition was applied: initial 3\% mobile phase B was increased linearly to $40 \%$ in $24 \mathrm{~min}$ and further to $85 \%$ and $95 \%$ for $5 \mathrm{~min}$ each before it was decreased to $3 \%$ and reequilibrated. The mass analysis method consisted of 1 segment with 10 scan events. The first scan event was an Orbitrap MS scan (300-1,800 m/z) with 60,000 resolution for parent ions followed by data-dependent MS/MS for fragmentation of the 10 most intense multiply charged ions with the collision-induced dissociation method.

\section{Identification of PTM in myoglobin}

The LC-MS/MS data were submitted to a local mascot server for MS/MS protein identification via Proteome Discoverer (version 1.3, Thermo Fisher Scientific, Waltham, MA) against a custom database containing only beef $\mathrm{Mb}$ protein (MYG_BOVIN) downloaded from UniProt (https://www.uniprot.org/ uniprot/P02192). Typical parameters used in the MASCOT MS/MS ion search were as follows: trypsin digestion with a maximum of 2 miscleavages; $10 \mathrm{ppm}$ precursor ion and 0.8-Da fragment ion mass tolerances; methionine oxidation; lysine acetylation; lysine and arginine methylation; serine, threonine, and tyrosine 
phosphorylation; 4-hydroxynonenal (HNE) alkylation at histidine, and lysine.

\section{Statistical analysis}

The LL muscles from $9(n=9)$ beef carcasses were utilized for the current study. A split-plot design with a completely randomized block design in the whole plot was utilized to evaluate the effects of postmortem aging time and display day on steak color and biochemical properties. In the whole plot, each LL muscle $(n=9)$ was cut into 4 sections. Each section within a muscle served as a whole plot unit and was randomly assigned to one of 4 aging periods $(0,7,14$, and $21 \mathrm{~d})$. The subplot experimental units consisted of steaks fabricated from each aged section assigned for 0,3 , or $6 \mathrm{~d}$ of refrigerated storage. Random effects included muscle (block) and muscle $\times$ aging period (error $\mathrm{A}$ ) for the whole plot and unspecified residual error (error B) for the subplot. The analysis of variance was determined utilizing the Mixed Procedure of SAS version 9.4 (SAS Institute Inc., Cary, NC), and the differences among means were detected using the least significant difference at a $5 \%$ level.

\section{Results and Discussion}

\section{Instrumental color and biochemical attributes}

$\boldsymbol{L}^{*}$ value (lightness). There was a significant aging $\times$ storage interaction $(P<0.05$; Table 1$)$ for lightness $\left(L^{*}\right.$ value). While non-aged steaks exhibited lower $(P<0.05) L^{*}$ value than aged counterparts on day 0 of storage, all the steaks demonstrated similar lightness $(P>0.05)$ at the end of storage $(6 \mathrm{~d})$. Nonaged steaks demonstrated an increase $(P<0.05)$ in $L^{*}$ value during the storage, whereas $L^{*}$ value remained stable $(P>0.05)$ in the aged ones. Overall, aging resulted in an increase in lightness, which was consistent with the observations of Marino et al. (2014), Obuz et al. (2014), English et al. (2016), and Nair et al. (2018a) in beef longissimus muscle.

Table 1. Surface lightness ( $L^{*}$ value), redness ( $a^{*}$ value), yellowness ( $b^{*}$ value), meat $\mathrm{pH}$, and Mb concentration of aged ${ }^{1}$ beef longissimus lumborum steaks $(n=9)$ during refrigerated storage $\left(2^{\circ} \mathrm{C}\right)$ for $6 \mathrm{~d}$ under aerobic packaging $^{2}$

\begin{tabular}{|c|c|c|c|c|}
\hline \multirow[t]{2}{*}{ Parameter } & \multirow[t]{2}{*}{ Aging days } & \multicolumn{3}{|c|}{ Storage days } \\
\hline & & 0 & 3 & 6 \\
\hline \multirow[t]{4}{*}{$L^{*}$ value } & 0 & $38.22 \pm 1.80^{\mathrm{c}}$ & $41.60 \pm 0.97^{b}$ & $42.11 \pm 1.46^{\mathrm{ab}}$ \\
\hline & 7 & $42.28 \pm 1.48^{\mathrm{ab}}$ & $42.77 \pm 1.31^{\mathrm{ab}}$ & $43.87 \pm 1.16^{\mathrm{a}}$ \\
\hline & 14 & $42.88 \pm 1.33^{\mathrm{ab}}$ & $43.02 \pm 0.95^{\mathrm{ab}}$ & $42.68 \pm 1.05^{\mathrm{ab}}$ \\
\hline & 21 & $42.99 \pm 1.51^{\mathrm{ab}}$ & $43.08 \pm 1.66^{\mathrm{ab}}$ & $42.20 \pm 0.90^{\mathrm{ab}}$ \\
\hline \multirow[t]{4}{*}{$a^{*}$ value } & 0 & $24.79 \pm 0.43^{\mathrm{a}}$ & $25.05 \pm 0.77^{\mathrm{a}}$ & $23.48 \pm 0.98^{\mathrm{ab}}$ \\
\hline & 7 & $25.77 \pm 0.62^{\mathrm{a}}$ & $24.60 \pm 0.42^{\mathrm{a}}$ & $21.81 \pm 0.93^{\mathrm{b}}$ \\
\hline & 14 & $24.56 \pm 0.57^{\mathrm{a}}$ & $23.53 \pm 0.86^{\mathrm{ab}}$ & $17.26 \pm 2.19^{c}$ \\
\hline & 21 & $24.85 \pm 0.34^{\mathrm{a}}$ & $23.19 \pm 0.77^{\mathrm{ab}}$ & $16.35 \pm 2.08^{c}$ \\
\hline \multirow[t]{4}{*}{$b^{*}$ value } & 0 & $19.55 \pm 0.63^{\mathrm{ab}}$ & $20.33 \pm 0.63^{\mathrm{a}}$ & $19.86 \pm 0.54^{\mathrm{ab}}$ \\
\hline & 7 & $20.31 \pm 0.46^{\mathrm{a}}$ & $19.25 \pm 0.30^{\mathrm{ab}}$ & $17.66 \pm 0.39^{b}$ \\
\hline & 14 & $18.99 \pm 0.53^{\mathrm{ab}}$ & $18.22 \pm 0.62^{\mathrm{b}}$ & $15.91 \pm 0.85^{\mathrm{c}}$ \\
\hline & 21 & $19.51 \pm 0.40^{\mathrm{ab}}$ & $18.47 \pm 0.40^{\mathrm{b}}$ & $15.99 \pm 0.81^{\mathrm{c}}$ \\
\hline \multirow[t]{4}{*}{ Meat pH } & 0 & $5.53 \pm 0.02^{\mathrm{c}}$ & $5.54 \pm 0.02^{\mathrm{c}}$ & $5.56 \pm 0.02^{\mathrm{bc}}$ \\
\hline & 7 & $5.62 \pm 0.02^{b}$ & $5.63 \pm 0.02^{b}$ & $5.61 \pm 0.01^{\mathrm{bc}}$ \\
\hline & 14 & $5.56 \pm 0.02^{\mathrm{bc}}$ & $5.62 \pm 0.02^{\mathrm{bc}}$ & $5.77 \pm 0.06^{\mathrm{a}}$ \\
\hline & 21 & $5.60 \pm 0.02^{\mathrm{bc}}$ & $5.63 \pm 0.01^{\mathrm{b}}$ & $5.80 \pm 0.06^{\mathrm{a}}$ \\
\hline \multirow[t]{4}{*}{ Mb concentration (mg/g) } & 0 & $6.00 \pm 0.33^{\mathrm{a}}$ & $5.34 \pm 0.20^{b}$ & $5.08 \pm 0.21^{\mathrm{c}}$ \\
\hline & 7 & $5.14 \pm 0.21^{\mathrm{bc}}$ & $4.98 \pm 0.23^{\mathrm{cd}}$ & $5.21 \pm 0.24^{\mathrm{bc}}$ \\
\hline & 14 & $4.74 \pm 0.24^{\mathrm{d}}$ & $4.68 \pm 0.31^{\mathrm{d}}$ & $4.58 \pm 0.25^{\mathrm{d}}$ \\
\hline & 21 & $4.63 \pm 0.25^{\mathrm{d}}$ & $4.79 \pm 0.34^{\text {cd }}$ & $4.51 \pm 0.28^{\mathrm{d}}$ \\
\hline
\end{tabular}


$a^{*}$ Value (redness). An aging $\times$ storage interaction $(P<0.05$; Table 1$)$ was observed for surface redness $\left(a^{*}\right.$ value). All steaks demonstrated similar redness $(P>0.05)$ on days 0 and 3 of storage. A decrease in redness upon aging $(P<0.05)$ was observed on day 6 of storage, with steaks aged for 14 and $21 \mathrm{~d}$ exhibiting the lowest redness. In general, redness of non-aged steaks remained stable during the storage $(P>0.05)$, whereas redness of aged ones decreased $(P<0.05)$. In agreement, Liu et al. (1996) observed that prolonged aging of beef LL accelerated the loss of redness. Postmortem aging can influence the cellular mechanisms that determine the $\mathrm{Mb}$ redox chemistry and therefore impact the meat color stability (Ledward, 1985; Tang et al., 2005; King et al., 2012). In addition, previous investigations reported that the decrease of redness in LL muscle during aging was possibly due to the negative effects of storage time on mitochondria-mediated metmyoglobin reduction (Mancini and Ramanathan, 2014) and mitochondrial degeneration (Mitacek et al., 2019). The increase in pH (Table 1) and lipid oxidation (Table 2) during aging and storage observed in the present study could also be responsible for the surface discoloration. The increase in $\mathrm{pH}$ observed in LL muscle could enhance mitochondria activity (Ramanathan and Mancini, 2018), resulting in the decrease of oxymyoglobin content as well as redness. Lipid oxidation, on the other hand, accelerates metmyoglobin formation, thus promoting discoloration in fresh meat (Faustman et al., 2010).

$b^{*}$ Value (yellowness). An interaction between aging and storage $(P<0.05$; Table 1$)$ was observed for yellowness $\left(b^{*}\right.$ value). While all steaks demonstrated similar yellowness at the beginning of the storage (day 0$)$, those aged for 14 and $21 \mathrm{~d}$ had lower $(P<$ $0.05)$ yellowness on storage days 3 and 6 than their counterparts aged for 0 and $7 \mathrm{~d}$. While the yellowness of non-aged steaks remained stable during storage, aged counterparts exhibited a decrease $(P<0.05)$ in yellowness. Overall, an increase in aging time resulted in rapid loss of yellowness during the storage in beef LL steaks. Our observation was consistent with previous investigations that documented that aging (Obuz et al., 2014) and storage (Joseph et al., 2012; Canto et al., 2015) resulted in the decrease of yellowness in beef LL steaks. On the contrary, Marino et al. (2014) documented that yellowness of longissimus dorsi muscle was not influenced by aging.

R630/580 (color stability). The R630/580 indicates surface color stability; a greater ratio reflects lower metmyoglobin content and thus greater color stability. There was no aging $\times$ storage interaction $(P>$ 0.05; Table 2) for R630/580. Nevertheless, both aging and storage led to the decrease $(P<0.05)$ of surface color stability of LL muscle. Muscles aged for 14 and $21 \mathrm{~d}$ demonstrated lower $(P<0.05)$ color stability

Table 2. Surface color stability (R630/580), MRA, and lipid oxidation of aged ${ }^{1}$ beef longissimus lumborum steaks $(n=9)$ during refrigerated storage $\left(2^{\circ} \mathrm{C}\right)$ for $6 \mathrm{~d}$ under aerobic packaging ${ }^{2}$

\begin{tabular}{|c|c|c|c|c|}
\hline \multirow[t]{2}{*}{ Parameter } & \multirow[t]{2}{*}{ Aging days } & \multicolumn{3}{|c|}{ Storage days } \\
\hline & & 0 & 3 & 6 \\
\hline \multirow[t]{4}{*}{ R630/580 } & 0 & $6.06 \pm 0.34^{\mathrm{ax}}$ & $5.12 \pm 0.33^{\text {ay }}$ & $4.52 \pm 0.34^{\mathrm{az}}$ \\
\hline & 7 & $5.50 \pm 0.26^{\mathrm{ax}}$ & $4.80 \pm 0.22^{\mathrm{ay}}$ & $3.97 \pm 0.27^{\mathrm{az}}$ \\
\hline & 14 & $5.09 \pm 0.28^{b x}$ & $4.46 \pm 0.30^{\text {by }}$ & $3.14 \pm 0.51^{\mathrm{bz}}$ \\
\hline & 21 & $5.16 \pm 0.23^{\mathrm{bx}}$ & $4.39 \pm 0.30^{\text {by }}$ & $2.94 \pm 0.46^{\mathrm{bz}}$ \\
\hline \multirow[t]{4}{*}{ MRA (\%) } & 0 & $48.88 \pm 3.99^{x}$ & $27.75 \pm 2.22^{\mathrm{y}}$ & $22.78 \pm 3.47^{y}$ \\
\hline & 7 & $45.05 \pm 2.02^{\mathrm{x}}$ & $30.39 \pm 3.45^{\mathrm{y}}$ & $19.16 \pm 4.51^{y}$ \\
\hline & 14 & $48.35 \pm 3.94^{\mathrm{x}}$ & $29.18 \pm 5.04^{y}$ & $31.35 \pm 8.08^{\mathrm{y}}$ \\
\hline & 21 & $41.76 \pm 2.39^{x}$ & $21.41 \pm 5.05^{\mathrm{y}}$ & $34.16 \pm 10.74^{x y}$ \\
\hline \multirow[t]{4}{*}{ Lipid oxidation $^{3}$} & 0 & $0.016 \pm 0.002^{\mathrm{bz}}$ & $0.028 \pm 0.004^{\text {by }}$ & $0.035 \pm 0.004^{\mathrm{bx}}$ \\
\hline & 7 & $0.020 \pm 0.002^{\mathrm{az}}$ & $0.047 \pm 0.009^{\mathrm{ay}}$ & $0.067 \pm 0.018^{\mathrm{ax}}$ \\
\hline & 14 & $0.029 \pm 0.004^{\mathrm{az}}$ & $0.046 \pm 0.012^{\mathrm{ay}}$ & $0.062 \pm 0.013^{\mathrm{ax}}$ \\
\hline & 21 & $0.027 \pm 0.008^{\mathrm{az}}$ & $0.048 \pm 0.009^{\text {ay }}$ & $0.067 \pm 0.015^{\mathrm{ax}}$ \\
\hline
\end{tabular}

\footnotetext{
${ }^{1}$ Aged in vacuum packaging at $2{ }^{\circ} \mathrm{C}$.

${ }^{2}$ Results expressed as mean \pm SEM.

${ }^{3}$ Result expressed as absorbance at $532 \mathrm{~nm}$.

${ }^{\mathrm{a}, \mathrm{b}}$ Means within a column without common superscript within an attribute are different $(P<0.05)$.

${ }^{\mathrm{x}-\mathrm{z}}$ Means within a row without common superscript are different $(P<0.05)$.

$\mathrm{MRA}=$ metmyoglobin reducing activity; R630/580 = ratio of reflectance at $630 \mathrm{~nm}$ and $580 \mathrm{~nm}$; SEM = standard error of the mean.
} 
than those aged for $7 \mathrm{~d}$ or less. In agreement, previous studies (Lindahl, 2011; English et al., 2016) recorded that beef discoloration increased with aging. Longer aging could decrease mitochondria function and metabolites required to generate $\mathrm{NADH}$ and therefore compromises color stability of beef (Ramanathan and Mancini, 2018). In addition, LL steaks exhibited a decrease $(P<0.05)$ in surface color stability during storage, and this observation was consistent with the results from previous investigations (Joseph et al., 2012; Canto et al., 2016; Nair et al., 2018a).

pH. There was an aging $\times$ storage interaction $(P<$ 0.05 ; Table 1) for $\mathrm{pH}$. The $\mathrm{pH}$ of steaks aged for 0 and $7 \mathrm{~d}$ remained stable over the storage, whereas steaks aged for 14 and $21 \mathrm{~d}$ exhibited an increase $(P<0.05)$ on day 6 of storage. In general, aging beyond $7 \mathrm{~d}$ resulted in higher $\mathrm{pH}$ of beef LL steaks at the end of $6 \mathrm{~d}$ of storage. The increase in the $\mathrm{pH}$ of aged meat during storage could be due to the proteolytic degradation of muscle fibers and the generation of basic metabolites (Lawrie, 1998). Likewise, Jayasooriya et al. (2007), Obuz et al. (2014), and Colle et al. (2015) documented that the $\mathrm{pH}$ of beef LL muscle increased with aging.

Myoglobin concentration. There was an aging $\times$ storage interaction $(P<0.05$; Table 1$)$ for Mb concentration. While all steaks experienced a decrease in $\mathrm{Mb}$ concentration during storage, the decline in non-aged steaks $(0 \mathrm{~d})$ - which demonstrated the highest $(P<$ $0.05) \mathrm{Mb}$ concentration-was more pronounced than their aged counterparts. Previous research (Jeong et al., 2009; King et al., 2011; McKenna et al., 2005) also indicated that the high content of $\mathrm{Mb}$ in muscles was associated with rapid discoloration. Muscle with a high level of $\mathrm{Mb}$ also contains a high concentration of iron, which is a prooxidant indirectly favoring the formation of metmyoglobin, leading to the decline in color stability (Farouk et al., 2007; Purchas et al., 2010).

Metmyoglobin reducing activity. The MRA indicates the ability of meat to reduce ferric metmyoglobin to ferrous redox forms (oxymyoglobin or deoxymyoglobin). The higher MRA suggests the greater inherent ability of muscle to reduce metmyoglobin, thus improving meat color stability. There was neither an aging $\times$ storage interaction $(P>0.05)$ nor an effect of aging $(P>0.05)$ for MRA (Table 2$)$. However, storage influenced $(P<0.001)$ MRA, with the greatest $(P<$ $0.05)$ values observed at the beginning of the storage (day 0). MRA decreased during storage in muscles aged for 0 and $7 \mathrm{~d}$, whereas MRA in 21-d-aged steaks had a tendency $(P>0.05)$ to increase from day 3 to day 6 of storage. Nair et al. (2018a) documented a similar pattern in beef psoas major muscle. Likewise, Bekhit et al. (2001) observed that sheep longissimus muscle at 6 wk postmortem had 20\% higher MRA than that at $48 \mathrm{~h}$ postmortem. Nair et al. (2018a) suggested that the tendency of increased MRA with storage could be possibly due to the increased degradation of mitochondria-releasing more mitochondrial enzymes - and subsequently increase of MRA without improving surface redness.

Lipid oxidation. There was no aging $\times$ storage interaction $(P>0.05)$ for TBARS (Table 2). However, there was an effect of storage $(P<0.001)$ and aging $(P=0.0062)$ on lipid oxidation. In agreement, several previous investigations documented that lipid oxidation in beef LL muscle increased with longer aging periods (Mancini and Ramanathan, 2014; Colle et al., 2015; English et al., 2016) and storage times (McKenna et al., 2005; Joseph et al., 2012; Mancini and Ramanathan, 2014; Colle et al., 2015; Canto et al., 2016). The observed increase in TBARS upon aging and storage could be attributed to the decrease in the redox capacity of meat and the generation of free radicals, which trigger the chain reaction and enhance lipid oxidation in meat (Min and Ahn, 2005). Previous investigations documented a decline in antioxidant capacity (Imazaki et al., 2018; Mitacek et al., 2019) and a decrease in the abundance of antioxidant enzymes (Nair et al., 2018b) in postmortem beef muscles upon aging. Endogenous antioxidants in postmortem skeletal muscles minimize lipid oxidation and metmyoglobin formation (Decker et al., 2000). A close positive correlation between lipid oxidation and $\mathrm{Mb}$ oxidation has been reported previously (Faustman and Cassens, 1990; Suman and Joseph, 2013). Lipid oxidationinduced $\mathrm{Mb}$ oxidation promotes the accumulation of metmyoglobin and leads to surface discoloration (Faustman et al., 2010).

\section{Differential PTM between myoglobin isoforms}

PTM can cause a shift in the pI of proteins by adding, removing, or changing titratable groups; this change in $\mathrm{pI}$ enables two-dimensional gel electrophoresis (2-DE) to resolve PTM-induced isoforms of proteins (Halligan et al., 2004). The representative 2-DE images (Figure 1) of beef sarcoplasmic proteome stained with Pro-Q Diamond (Invitrogen) for phosphorylated protein (Figure 1A) and Sypro Ruby (Invitrogen) for total protein (Figure 1B) are presented. Six $\mathrm{Mb}$ isoforms appeared in the gel images with similar molecular weight $(17 \mathrm{kDa})$ but different $\mathrm{pI}$, presenting the "beads on a string" appearance. These $6 \mathrm{Mb}$ spots 


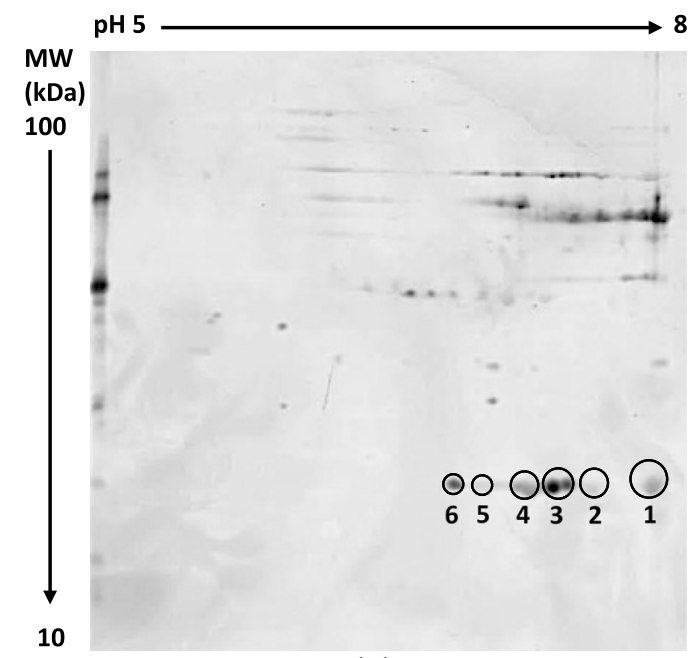

(a)

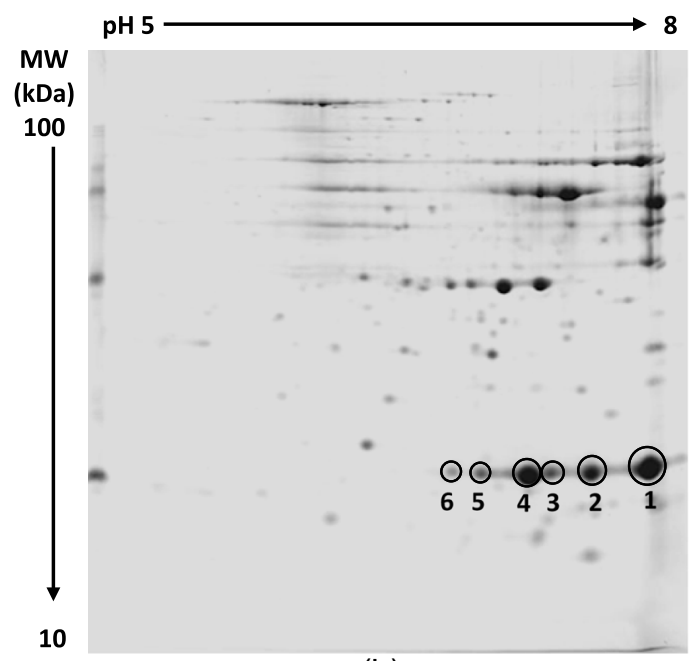

(b)

Figure 1. Representative two-dimensional gel electrophoresis map of sarcoplasmic proteome extracted from beef longissimus lumborum. The gel was stained with Pro-Q Diamond for (a) phosphorylated protein and with Sypro Ruby for (b) total protein. Myoglobin spots with the same number are located at the same position (isoelectric point and molecular weight $[\mathrm{MW}]$ ) across the gels.

migrated different distances to the acidic side of the gel and exhibited different $\mathrm{pI}$, indicating that they were post-translationally modified to different degrees. Similarly, Canto et al. (2015) identified 4 spots with similar molecular weight and different $\mathrm{pI}$ on 2-DE as beef $\mathrm{Mb}$, yet the PTM in those spots were not identified.

Data in Table 3 indicated that the greatest number of phosphorylation sites were detected in isoform 3 (spot 3), whereas the sites of acetylation and carboxymethylation were most abundant in isoform 2 (spot 2). The largest number of methylation sites were observed in isoform 4 (spot 4). Phosphorylation, acetylation, methylation, and carboxymethylation could contribute to the $\mathrm{pI}$ shift by the addition of phosphates (McLachlin and Chait, 2001; Halligan et al., 2004; Jensen, 2004), acetyl group (Kumar et al., 2004; Xie et al., 2007), methyl group (Zhu et al., 2005; Xie et al., 2007), and carboxylic acid (Kung, 1976), respectively. The addition of negatively charged groups to the protein would cause its migration toward the acidic side of the gel (Anderson et al., 2014). Nonetheless, the magnitude of the $\mathrm{pI}$ shift will be dependent on the number and chemistry of the titratable groups added to the protein. Kumar et al. (2004) observed a direct relationship between the number of residues phosphorylated in a protein and the pI shift. Furthermore, Halligan et al. (2004) indicated that phosphates add 1.5 negative charge to the protein at a $\mathrm{pH}$ near 6.5 . On the other hand, the pI shift due to acetylation is generally small $(<0.2 \mathrm{pH}$; Zhu et al., 2005). Kumar et al. (2004) indicated that phosphorylation causes a greater shift in $\mathrm{pI}$ than acetylation and methylation. Therefore, the combination of different PTM could have contributed to the pI shifts of the isoforms 2, 3, and 4.

Spot 1 (the most alkaline isoform with the greatest $\mathrm{pI}$ ) representing the native form of $\mathrm{Mb}$ was observed to have HNE alkylation at the greatest extent (Table 3). HNE could adduct to the imidazole group of histidine residues and the amine group of lysine, forming Michael adducts (Esterbauer et al., 1991). The addition of HNE has a minimal effect on the $\mathrm{pI}$ compared with other PTM, which introduce negatively charged groups (phosphates, acetyl group, and carboxylic acid) to the protein. This could possibly be the reason why spot 1 exhibited no change in the $\mathrm{pI}$.

The $\mathrm{Mb}$ isoforms in spots 5 and 6 migrated further to the acidic side of the gel, suggesting that they were post-translationally modified at a greater degree than the other isoforms. However, the number of sites of PTM were lower in these 2 isoforms than in the other ones (Table 3). Phosphorylation was the major PTM in the isoforms 5 and 6 (Table 3 ), and this could have contributed to greater shift in $\mathrm{pI}$ of these 2 isoforms compared with the other isoforms in which a variety of PTM were identified.

\section{PTM patterns in beef myoglobin}

The position and identity of amino acids in beef $\mathrm{Mb}$ that underwent various PTM are summarized in Figure 2. The amino acids susceptible to phosphorylation were serine $(\mathrm{S})$, threonine $(\mathrm{T})$, and tyrosine $(\mathrm{Y})$, whereas other PTM are detected in lysine $(\mathrm{K})$, arginine 
Table 3. Post-translational modifications and their locations in myoglobin isoforms isolated from beef longissimus lumborum muscle from all aging days

\begin{tabular}{|c|c|c|c|c|c|c|}
\hline \multirow[b]{2}{*}{ Post-translational modifications } & \multicolumn{6}{|c|}{ Myoglobin spots ${ }^{\mathrm{a}}$} \\
\hline & Spot 1 & Spot 2 & Spot 3 & Spot 4 & Spot 5 & Spot 6 \\
\hline \multirow[t]{7}{*}{ Phosphorylation } & 51 Threonine & 67 Threonine & 34 Threonine & 34 Threonine & 34 Threonine & 70 Threonine \\
\hline & 58 Serine & 103 Tyrosine & 67 Threonine & 51 Threonine & 67 Threonine & 103 Tyrosine \\
\hline & 67 Threonine & & 70 Threonine & 58 Serine & 70 Threonine & 108 Serine \\
\hline & & & 103 Tyrosine & & 103 Tyrosine & 121 Serine \\
\hline & & & 108 Serine & & 132 Serine & \\
\hline & & & 121 Serine & & & \\
\hline & & & 132 Serine & & & \\
\hline \multirow[t]{8}{*}{ Acetylation } & 50 Lysine & 56 Lysine & 50 Lysine & 63 Lysine & 63 Lysine & - \\
\hline & 63 Lysine & 63 Lysine & 56 Lysine & 77 Lysine & 77 Lysine & \\
\hline & 77 Lysine & 77 Lysine & 63 Lysine & 78 Lysine & 78 Lysine & \\
\hline & 78 Lysine & 78 Lysine & 77 Lysine & 79 Lysine & 147 Lysine & \\
\hline & 79 Lysine & 79 Lysine & 78 Lysine & & & \\
\hline & 118 Lysine & 87 Lysine & 79 Lysine & & & \\
\hline & & 118 Lysine & 118 Lysine & & & \\
\hline & & 133 Lysine & & & & \\
\hline \multirow[t]{9}{*}{ Methylation } & 31 Arginine & 31 Arginine & 31 Arginine & 31 Arginine & 77 Lysine & 56 Lysine \\
\hline & 42 Lysine & 42 Lysine & 42 Lysine & 42 Lysine & 78 Lysine & \\
\hline & 56 Lysine & 62 Lysine & 77 Lysine & 56 Lysine & 139 Arginine & \\
\hline & 62 Lysine & 63 Lysine & 78 Lysine & 62 Lysine & & \\
\hline & 63 Lysine & 98 Lysine & 79 Lysine & 63 Lysine & & \\
\hline & 118 Lysine & 102 Lysine & 118 Lysine & 96 Lysine & & \\
\hline & 133 Lysine & 118 Lysine & 139 Arginine & 98 Lysine & & \\
\hline & 139 Arginine & & & 118 Lysine & & \\
\hline & & & & 133 Lysine & & \\
\hline \multirow[t]{12}{*}{ Carboxymethylation } & 62 Lysine & 56 Lysine & 56 Lysine & 62 Lysine & - & 62 Lysine \\
\hline & 63 Lysine & 62 Lysine & 62 Lysine & 63 Lysine & & 77 Lysine \\
\hline & 77 Lysine & 63 Lysine & 63 Lysine & 77 Lysine & & 78 Lysine \\
\hline & 78 Lysine & 77 Lysine & 77 Lysine & 78 Lysine & & \\
\hline & 102 Lysine & 78 Lysine & 78 Lysine & 118 Lysine & & \\
\hline & 118 Lysine & 79 Lysine & 79 Lysine & 133 Lysine & & \\
\hline & 133 Lysine & 87 Lysine & 102 Lysine & & & \\
\hline & 147 Lysine & 96 Lysine & 118 Lysine & & & \\
\hline & & 98 Lysine & 133 Lysine & & & \\
\hline & & 102 Lysine & 147 Lysine & & & \\
\hline & & 133 Lysine & & & & \\
\hline & & 147 Lysine & & & & \\
\hline \multirow[t]{9}{*}{ HNE alkylation } & 45 Lysine & 77 Lysine & 77 Lysine & 56 Lysine & - & 77 Lysine \\
\hline & 47 Lysine & 78 Lysine & 78 Lysine & 62 Lysine & & \\
\hline & 56 Lysine & 79 Lysine & 79 Lysine & 63 Lysine & & \\
\hline & 62 Lysine & & & 64 Histidine & & \\
\hline & 63 Lysine & & & & & \\
\hline & 64 Histidine & & & & & \\
\hline & 77 Lysine & & & & & \\
\hline & 78 Lysine & & & & & \\
\hline & 79 Lysine & & & & & \\
\hline
\end{tabular}

${ }^{\mathrm{a}}$ Spot number refers to the numbered spots in gel images (Figure 1A-1B).

$\mathrm{HNE}=$ 4-hydroxynonenal. 


\begin{tabular}{|c|c|c|c|c|c|c|}
\hline Sequence No. & 10 & 20 & 30 & 40 & 50 & \\
\hline Phosphorylation & GLSDGEWQLV & LNAWGKVEAD & VAGHGQEVLI & RLFTGHPETL & EKFDKFKHLK & \\
\hline Acetylation & GLSDGEWQLV & LNAWGKVEAD & VAGHGQEVLI & RLFTGHPETL & EKFDKFKHLK & \\
\hline Methylation & GLSDGEWQLV & LNAWGKVEAD & VAGHGQEVLI & RLFTGHPETL & EKFDKFKHLK & \\
\hline Carboxymethylation & GLSDGEWQLV & LNAWGKVEAD & VAGHGQEVLI & RLFTGHPETL & EKFDKFKHLK & \\
\hline HNE Alkylation & GLSDGEWQLV & LNAWGKVEAD & VAGHGQEVLI & RLFTGHPETL & EKFDKKFKHLK & \\
\hline Sequence No. & 60 & 70 & 80 & 90 & 100 & \\
\hline Phosphorylation & TEAEMKASED & LKKHGNTVLT & ALGGILKKKG & HHEAEVKHLA & ESHANKHKIP & \\
\hline Acetylation & TEAEMKASED & LKKKHGNTVLT & ALGGILKKKG & HHEAEVKHLA & ESHANKHKIP & \\
\hline Methylation & TEAEMKASED & LKKHGNTVLT & ALGGILKKKG & HHEAEVKHLA & ESHANKHKIP & \\
\hline Carboxymethylation & TEAEMKASED & LKKHGNTVLT & ALGGILKKKG & HHEAEVKHLA & ESHANKHKIP & \\
\hline HNE Alkylation & TEAEMKASED & LKKHGNTVLT & ALGGILKKKG & HHEAEVKHLA & ESHANKHKIP & \\
\hline Sequence No. & 110 & 120 & 130 & 140 & 150 & 153 \\
\hline Phosphorylation & VKY YLEFISDAA & IIHVLHAKHP & SDFGADAQAA & MSKKALELFRN & DMAAQYKVLG & FHG \\
\hline Acetylation & VKYLEFISDA & IIHVLHAKHP & SDFGADAQAA & MSKALELFRN & DMAAQYKVLG & FHG \\
\hline Methylation & VKYLLEFISDA & IIHVLHAKHP & SDFGADAQAA & MSKKALELFRN & DMAAQYKVLG & FHG \\
\hline Carboxymethylation & VKYLEEFISDA & IIHVLHAKHP & SDFGADAQAA & MSKKALELFRN & DMAAQYKVLG & FHG \\
\hline HNE Alkylation & VKYLEFISDA & IIHVLHAKHP & SDFGADAQAA & MSKALELFRN & DMAAQYKVLG & FHG \\
\hline
\end{tabular}

Figure 2. Post-translational modifications (phosphorylation, acetylation, methylation, carboxymethylation, 4-hydroxynonenal [HNE] alkylation) and their locations in the amino acid sequence of beef myoglobin. Post-translationally modified residues are underlined.

$(\mathrm{R})$, and histidine $(\mathrm{H})$ residues. Moreover, lysine residues at positions $56,63,77,78,79,118$, and 132 were susceptible to several PTM, namely acetylation, methylation, and carboxymethylation. A variety of factors, such as the number of PTM in a molecule of protein as well as their chemistry and location(s), influence protein functionality (Kumar et al., 2004).

Phosphorylation sites in myoglobin. Phosphorylation is the most common PTM and is a key regulator of biological/cellular processes (Graves and Krebs, 1999; Hunter, 2000). Phosphorylation has been reported in $\mathrm{Mb}$ from beluga whale (Stewart et al., 2004), human (Hojlund et al., 2009), pork (Huang et al., 2011; Lametsch et al., 2011), and sheep (Li et al., 2017, 2018a, 2018b). Moreover, Li et al. (2018a, 2018b) documented that the degree of phosphorylation in sheep $\mathrm{Mb}$ was inversely related to lamb color stability. Nonetheless, the impact of phosphorylation on the functionality of beef $\mathrm{Mb}$ is yet to be understood.

Phosphorylation was identified in the serine (positions 58, 108, 121, and 132), threonine (positions 34, 51, 67, and 70), and tyrosine (position 103) residues of beef $\mathrm{Mb}$ (Figure 2). In agreement, previous studies reported that serine, threonine, and tyrosine are the 3 amino acids that are most susceptible to phosphorylation (Hunter, 2012; Ardito et al., 2017; Lin, 2018). Similar to our results, Li et al. (2018b) documented phosphorylation at T34, T51, S58, T67, T70, Y103, S121, and S132 in sheep Mb. Furthermore, Hojlund et al. (2009) identified phosphorylation at T67 and $\mathrm{T} 70$ in human $\mathrm{Mb}$.

In the three-dimensional model of beef $\mathrm{Mb}$ (Figure 3), T34, T51, T70, and S121 residues are located on the surface and thus are readily accessible to protein kinase, which is the enzyme responsible for catalyzing phosphorylation. In support, Stewart et al. (2004) suggested that S117 in beluga whale $\mathrm{Mb}$ was a site for phosphorylation and is located on the $\mathrm{Mb}$ surface making it easily accessible to protein kinase. A phosphate group added to $\mathrm{Mb}$ could form intra- and inter-molecular hydrogen bonds or salt bridges and thus alter the interaction of the heme protein with other small biomolecules (Hunter, 2012; Ardito et al., 2017).

Threonine at position 67 (T67) is located in the vicinity of distal histidine (position 64) in beef $\mathrm{Mb}$ 


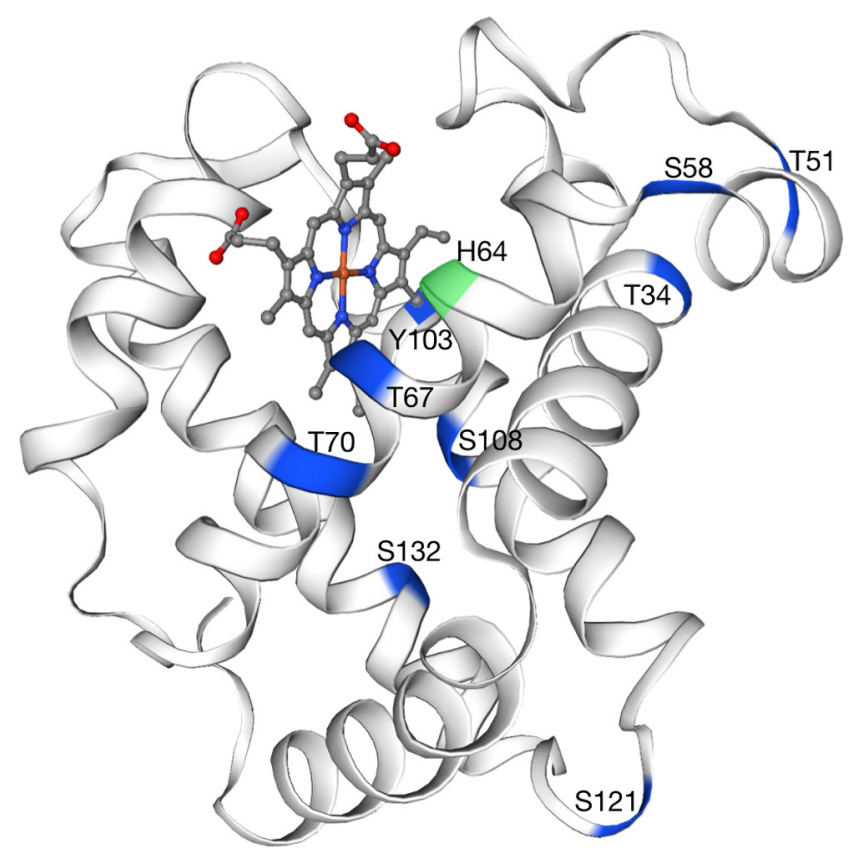

Figure 3. Threonine (T34, T51, T67, and T70), serine (S58, S108, $\mathrm{S} 121$, and S132), and tyrosine (Y103) residues in beef myoglobin are indicated in blue, whereas distal histidine (H64) is in green. The residues in blue were phosphorylated. The three-dimensional homology model of beef myoglobin was downloaded from SWISS-MODEL (Waterhouse et al., 2018).

(Figure 3), which is critical to the oxygen binding capability and redox stability (Suman and Joseph, 2013). The addition of a negative phosphate group on T67 influences the distal histidine's spatial interaction with hydrophobic heme pocket, increases the heme pocket's polarity, and decreases oxygen binding (Cameron et al., 1993). In partial agreement, Livingston et al. (1986) suggested that $\mathrm{T} 67 \mathrm{in} \mathrm{Mb}$ from yellowfin tuna, turtle, and sperm whale could be involved with ligand binding. Likewise, Stewart et al. (2004) reported that the substitution of valine at position 67 with threonine in beluga whale $\mathrm{Mb}$ influenced the distal histidine's role in oxygen binding ability of heme. Additionally, Li et al. (2018b) suggested that the phosphorylation of sheep $\mathrm{Mb}$ at S132 might compromise the heme protein's oxygen binding ability and thus plays a negative role in color stability. Sheep and beef cattle $\mathrm{Mb}$ share $98.7 \%$ similarity in amino acid sequence (Suman and Joseph, 2013); therefore, it is possible that the phosphorylation at $\mathrm{S} 132$ in beef $\mathrm{Mb}$ could be detrimental to its oxygen binding capability and redox stability.

Acetylation sites in myoglobin. Protein acetylation is involved in essential biological processes (Zhao et al., 2010; Kwan et al., 2016; Ali et al., 2018). Previous investigations have documented acetylation of lysine in $\mathrm{Mb}$ from yellowfin tuna (Rice et al., 1979), cattle (Livingston et al., 1985), bullet tuna
(Ueki et al., 2005), and pig (Jiang et al., 2019). In the present study, 10 lysine residues (positions 50, $56,63,77,78,79,87,118,133$, and 147) were found to be acetylated in beef $\mathrm{Mb}$. These 10 positively charged lysine residues are located on the surface in beef $\mathrm{Mb}$. Charged residues play critical roles in protein stability through the formation of ionic networks (Strickler et al., 2006; Pace et al., 2009; Raghunathan et al., 2013). Therefore, the addition of acetyl groups may neutralize the positively charged lysine residues, disrupting the charge distribution and altering the ionic network of $\mathrm{Mb}$. Attachment of acetyl groups to surface lysine residues in $\mathrm{Mb}$ could decrease the protein's hydrophilicity and induce unfolding, and this in turn could expose the heme pocket to oxidizing agents, thus promoting heme iron release and jeopardizing oxygen binding ability. In partial agreement, Azami-Movahed et al. (2018) observed that horse apomyoglobin underwent acetylation-induced conformational changes with less ordered tertiary structure and absence of stable hydrophobic patches due to heme pocket disruption. Likewise, Nguyen et al. (2000) suggested that the Nterminus acetylation altered orientation of heme and proximal histidine imidazole plane in Mb from Aplysia limacine (sea hare). Moreover, Jiang et al. (2019) observed acetylation of K43 and K78 in pig Mb and suggested that lysine acetylation may be related to meat quality.

Methylation sites in myoglobin. Methylation is a distinct PTM that contributes to minimal change in size and electrostatic status to lysine and arginine residues (Luo, 2018). This PTM is also involved in a number of biological processes (Ong et al., 2004; Uhlmann et al., 2012). Methylation has been identified in histone (Greer and Shi, 2012; Lanouette et al., 2014; Clarke, 2018; Luo, 2018), ribosomal protein (Pang et al., 2010), tumor suppressor p53 (Huang and Berger, 2008), heat shock proteins (Abu-Farha et al., 2011), myosin (Li et al., 2015), and hemoglobin (Chen et al., 2017).

Methylation sites were detected in arginine (positions 31 and 139) and lysine (positions 42, 56, 62, 63, $77,78,79,96,98,102,118$, and 133) residues in beef $\mathrm{Mb}$. The aforementioned methylation sites are adjacent to hydrophobic residues such as leucine (L), isoleucine (I), alanine (A), and phenylalanine (F) in the amino acid sequence (Figure 2). This observation was consistent with previous report (Bremang et al., 2013), which reported that the amino acid residues near the methylated sites in proteins were predominantly hydrophobic in nature. Moreover, the methylation site K56 in $\mathrm{Mb}$ (Figure 2) conforms with the methionine-lysine 
methylation motif reported by Pang et al. (2010), indicating that K56 might be methylated by a specific methyl transferase. The addition of methyl groups could increase hydrophobicity and steric hindrance and, in turn, alter the stability of proteins (Bremang et al., 2013). The methylation at K62 and K63 could impact distal histidine's (H64) interactions with heme pocket (Figure 4) and compromise Mb redox stability. Likewise, the addition of methyl groups at K96 and K98 might affect the proximal histidine (H93) in the vicinity (Figure 4), which connects heme to the globin chain, and consequently influence the oxygen binding ability/oxygen affinity. Additionally, the 11 sites (K56, K62, K63, K77, K78, K79, K96, K98, K102, K118, and K133) of methylation were also susceptible to other PTM (acetylation, carboxymethylation, and HNE alkylation), indicating the existence of PTM crosstalk (Aggarwal et al., 2020). PTM crosstalk is defined as the interactions between co-occurring multiple PTM, which can positively or negatively influence each other's occurrence (van der Laarse et al., 2018). The crosstalk among PTM could alter protein functions (Zhang et al., 2015). Furthermore, methylation could decrease protein stability by acting in combination with other PTM (Pang et al., 2010; Moore and Gozani, 2014; Zhang et al., 2015; Wu et al., 2017). Therefore, it is highly possible that the interplay between

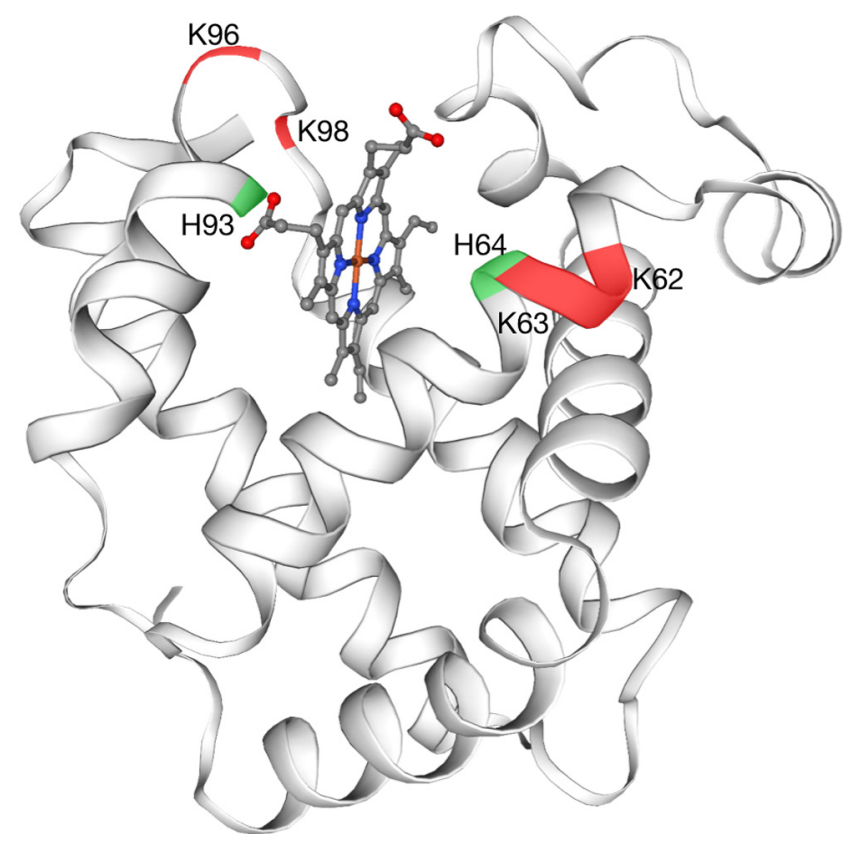

Figure 4. Distal (H64) and proximal (H93) histidines in beef myoglobin are indicated in green, whereas lysine residues (K62, K63, K96, and $\mathrm{K} 98$ ) are in red. The three-dimensional homology model of beef myoglobin was downloaded from SWISS-MODEL (Waterhouse et al., 2018). the PTM at aforementioned 11 lysine residues (methylation sites) could decrease Mb redox stability.

Carboxymethylation sites in myoglobin. Carboxymethylation is a nonenzymatic PTM and is a potential metabolic modulator in chemotaxis, neurosecretory regulation, and diabetes (Diliberto et al., 1976; Curtiss and Witztum, 1985; Hackett and Campochiaro, 1988; Fang et al., 2010). Carboxymethylation could be achieved in vitro chemically (using bromoacetate) in the $\mathrm{Mb}$ from human (Harris and Hill, 1969), sperm whale (Banaszak et al., 1963; Ray and Gurd, 1967; Schlecht, 1969; Hugli and Gurd, 1970; Wu et al., 1972) and harbor seal (Nigen and Gurd, 1973). However, $\mathrm{Mb}$ carboxymethylation has not been investigated in postmortem skeletal muscle tissue.

Carboxymethylation was identified in 13 lysine residues (positions 56, 62, 63, 77, 78, 79, 87, 96, 98, $102,118,133$, and 147) in beef Mb. Carboxymethylation introduces negatively charged carboxylic acid to the positively charged lysine residues located on the $\mathrm{Mb}$ surface, which could alter the ionic network and lead to conformational changes (Fang et al., 2010). Furthermore, carboxymethylation at K62 and K63, which are adjacent to the distal histidine (H64; Figure 4), might induce a spatial rearrangement of heme pocket, influencing the oxygen affinity of beef $\mathrm{Mb}$ and the color stability of steaks. Additionally, the loss of positive charge of K96 and K98 in the vicinity of proximal histidine (H93) could disrupt the heme iron-proximal histidine bond, compromising the heme affinity and damaging $\mathrm{Mb}$ helical structure (Smerdon et al., 1993; Hargrove et al., 1996). In agreement, Wu et al. (1972) observed that carboxymethylated sperm whale $\mathrm{Mb}$ (chemically modified) underwent autoxidation faster than its unmodified counterpart, indicating that carboxymethylation could compromise $\mathrm{Mb}$ redox stability.

HNE alkylation sites in myoglobin. $\mathrm{HNE}$ is an $\alpha, \beta$-unsaturated aldehyde formed as a result of oxidation of $\omega-6$ polyunsaturated fatty acids (Esterbauer et al., 1991), which are present abundantly in the membrane phospholipids of skeletal muscles (Wood et al., 2008). The electrophilic nature of carbon 3 in HNE enables it to covalently bind to nucleophilic sidechains of lysine and histidine residues (Esterbauer et al., 1991; Uchida and Stadtman, 1992). Alkylation of proteins by HNE has been reported to cause cytotoxicity (Codreanu et al., 2014; Yang et al., 2015). In in vitro model systems, HNE alkylation through Michael addition has been identified at histidine residues of $\mathrm{Mb}$ from beef (Alderton et al., 2003; Suman et al., 2006, 2007), pork (Suman et al., 2006, 2007; Elroy et al., 2015), 
sheep (Yin et al., 2011), horse (Faustman et al., 1999), sperm whale (Tatiyaborworntham et al., 2012), yellowfin tuna (Lee et al., 2003), ostrich (Nair et al., 2014), emu (Nair et al., 2014), turkey (Naveena et al., 2010), and chicken (Naveena et al., 2010). However, in situ $\mathrm{HNE}$ alkylation of $\mathrm{Mb}$ in muscle foods has yet to be reported.

In the present study, histidine (position 64) and lysine (positions 45, 47, 56, 62, 63, 77, 78, and 79) residues were modified by HNE alkylation in beef $\mathrm{Mb}$. Histidine and lysine residues form cyclic hemiacetal derivatives (Uchida and Stadtman, 1992, 1993; Uchida, 2003) via Michael addition with HNE. Alkylation at distal histidine (position 64), which is critical for heme stability, could destabilize heme iron's ability to bind with oxygen and therefore compromise $\mathrm{Mb}$ redox stability and beef color stability (Suman and Joseph, 2013). In agreement, previous investigations (Alderton et al., 2003; Suman et al., 2007; Viana et al., 2020) observed that HNE alkylation at $\mathrm{H} 64$ enhances oxidation of beef $\mathrm{Mb}$. Additionally, the Michael adducts formed at lysine residues (positions 45, 47, $56,62,63,77,78$, and 79) - especially at K62 and $\mathrm{K} 63$, which are located adjacent to the distal histidine (Figure 4)-could compromise hydrophobic interactions stabilizing the tertiary structure of $\mathrm{Mb}$, leading to globin unfolding (Ueki and Ochiai, 2006).

\section{Aging-induced PTM influence beef color stability}

The sites of PTM in beef Mb during $21 \mathrm{~d}$ of postmortem aging are presented in Table 4. Total PTM sites increased with aging from day 0 to day 14 , whereas it decreased thereafter. The decrease in number of detected PTM from day 14 to day 21 of aging is possibly due to the observed decrease in the Mb concentration (Table 1) as a result of protein degradation and drip loss.

Increased numbers of phosphorylation, methylation, and carboxymethylation sites were observed in $\mathrm{Mb}$ from aged beef compared with $\mathrm{Mb}$ from non-aged counterparts (Table 4). The increased number of phosphate groups, methyl groups, and carboxylic acid adducted to $\mathrm{Mb}$ could disrupt the ionic network, which is critical to the heme protein's stability. Moreover, phosphorylation at $\mathrm{T} 51$ and $\mathrm{S} 121$; methylation at R31, K77, K78, K79, K96, K98, K102, K133, and $\mathrm{R} 139$; and carboxymethylation at K56, K96, K98, $\mathrm{K} 118$, and $\mathrm{K} 147$ were unique to $\mathrm{Mb}$ from aged beef, whereas carboxymethylation at K79 and K87 were unique to $\mathrm{Mb}$ from non-aged counterparts (Table 5).
The PTM at K96 and K98 observed in Mb from aged beef could influence the interactions between proximal histidine (H93) and heme iron (Figure 4), compromising the protein's heme affinity and redox state (Hargrove et al., 1996; Grunwald and Richards, 2006). Previous studies have indicated that minor variations in amino acid sequence of $\mathrm{Mb}$, especially those close to the heme pocket, could alter autoxidation rate (Kitahara et al., 1990; Tada et al., 1998), heme affinity (Grunwald and Richards, 2006), and structural stability (Ueki and Ochiai, 2004, 2006). Therefore, the decreased color stability in aged beef could be attributed to the increased number of PTM (phosphorylation, methylation, carboxymethylation).

$\mathrm{Mb}$ acetylation sites decreased during postmortem aging (Table 4). In agreement, a decrease in acetylation was observed in proteins during postmortem aging of pork longissimus muscle (Jiang et al., 2019). In addition, the dynamic acetylation-deacetylation of lysine residues could influence the conversion of muscle to meat and meat quality (Jiang et al., 2019). Acetylation can regulate stability of $\mathrm{Mb}$ and its interactions with other proteins by converting positively charged $\mathrm{NH}_{4}{ }^{+}$cation on lysine and arginine residues into a neutral moiety (Kumar et al., 2004; Zhu et al., 2005; Krueger and Srivastava, 2006; Xie et al., 2007). Moreover, acetylation at K87 and K118 were unique to $\mathrm{Mb}$ from non-aged beef, whereas acetylation at $\mathrm{K} 56$ and $\mathrm{K} 147$ were unique to $\mathrm{Mb}$ from aged beef (Table 5). Therefore, aging might cause the deacetylation at K87 and K118-and acetylation at K56 and $\mathrm{K} 147$ - and, in turn, regulate $\mathrm{Mb}$ redox stability and color stability of beef.

The number of HNE alkylation sites in $\mathrm{Mb}$ did not change during $14 \mathrm{~d}$ of aging (Table 4). Nevertheless, HNE alkylation at K45 and K47 were only detected in $\mathrm{Mb}$ from non-aged beef, whereas K78 and K79 were adducted by HNE only in $\mathrm{Mb}$ from aged counterparts (Table 5). Covalent binding of HNE to lysine residues compromises the tertiary structure of proteins and increases its susceptibility to oxidation (Isom et al., 2004; Szapacs et al., 2006); therefore, aging-induced HNE alkylation of lysine residues might play a critical role in Mb redox stability (Suman and Joseph, 2013). Additionally, distal histidine (H64) was alkylated in $\mathrm{Mb}$ from both non-aged and aged beef (Table 5). Our results were different from in vitro studies of Suman et al. (2006) and Viana et al. (2020), in which beef $\mathrm{Mb}$ was incubated with HNE at meat conditions. While Suman et al. (2006) identified 4 HNE adducted histidine residues (position 36, 81, 88, and 152) of beef $\mathrm{Mb}$, the present study found only 1 histidine (H64) 
Table 4. Post-translational modifications and their locations in myoglobin isolated from beef longissimus lumborum muscle during postmortem aging

\begin{tabular}{|c|c|c|c|c|}
\hline \multirow[t]{2}{*}{ Post-translational modifications } & \multicolumn{4}{|c|}{ Aging days } \\
\hline & $0 \mathrm{~d}$ & $7 \mathrm{~d}$ & $14 \mathrm{~d}$ & $21 \mathrm{~d}$ \\
\hline \multirow[t]{9}{*}{ Phosphorylation } & 34 Threonine & 34 Threonine & 34 Threonine & 34 Threonine \\
\hline & 58 Serine & 51 Threonine & 58 Serine & 67 Threonine \\
\hline & 67 Threonine & 58 Serine & 67 Threonine & 70 Threonine \\
\hline & 70 Threonine & 67 Threonine & 70 Threonine & 103 Tyrosine \\
\hline & 103 Tyrosine & 70 Threonine & 103 Tyrosine & 108 Serine \\
\hline & 108 Serine & 103 Tyrosine & 108 Serine & 132 Serine \\
\hline & 132 Serine & 108 Serine & 121 Serine & \\
\hline & & 121 Serine & 132 Serine & \\
\hline & & 132 Serine & & \\
\hline \multirow[t]{8}{*}{ Acetylation } & 50 Lysine & 56 Lysine & 50 Lysine & 63 Lysine \\
\hline & 63 Lysine & 63 Lysine & 56 Lysine & 77 Lysine \\
\hline & 77 Lysine & 77 Lysine & 63 Lysine & 78 Lysine \\
\hline & 78 Lysine & 78 Lysine & 77 Lysine & 147 Lysine \\
\hline & 79 Lysine & 79 Lysine & 78 Lysine & \\
\hline & 87 Lysine & 133 Lysine & 79 Lysine & \\
\hline & 118 Lysine & & & \\
\hline & 133 Lysine & & & \\
\hline \multirow[t]{12}{*}{ Methylation } & 42 Lysine & 31 Arginine & 31 Arginine & 31 Arginine \\
\hline & 56 Lysine & 42 Lysine & 42 Lysine & 42 Lysine \\
\hline & 62 Lysine & 56 Lysine & 56 Lysine & 63 Lysine \\
\hline & 63 Lysine & 62 Lysine & 62 Lysine & 77 Lysine \\
\hline & 118 Lysine & 63 Lysine & 63 Lysine & 78 Lysine \\
\hline & & 77 Lysine & 77 Lysine & 98 Lysine \\
\hline & & 78 Lysine & 78 Lysine & 102 Lysine \\
\hline & & 79 Lysine & 98 Lysine & 118 Lysine \\
\hline & & 96 Lysine & 102 Lysine & 133 Lysine \\
\hline & & 98 Lysine & 118 Lysine & \\
\hline & & 118 Lysine & 133 Lysine & \\
\hline & & 139 Arginine & & \\
\hline \multirow[t]{11}{*}{ Carboxymethylation } & 62 Lysine & 56 Lysine & 56 Lysine & 62 Lysine \\
\hline & 63 Lysine & 62 Lysine & 62 Lysine & 63 Lysine \\
\hline & 77 Lysine & 63 Lysine & 63 Lysine & 77 Lysine \\
\hline & 78 Lysine & 77 Lysine & 77 Lysine & 78 Lysine \\
\hline & 79 Lysine & 78 Lysine & 78 Lysine & 133 Lysine \\
\hline & 87 Lysine & 96 Lysine & 102 Lysine & \\
\hline & 102 Lysine & 98 Lysine & 118 Lysine & \\
\hline & 133 Lysine & 102 Lysine & 147 Lysine & \\
\hline & & 118 Lysine & & \\
\hline & & 133 Lysine & & \\
\hline & & 147 Lysine & & \\
\hline \multirow[t]{7}{*}{ HNE alkylation } & 45 Lysine & 56 Lysine & 56 Lysine & 77 Lysine \\
\hline & 47 Lysine & 62 Lysine & 62 Lysine & \\
\hline & 56 Lysine & 63 Lysine & 63 Lysine & \\
\hline & 62 Lysine & 64 Histidine & 64 Histidine & \\
\hline & 63 Lysine & 77 Lysine & 77 Lysine & \\
\hline & 64 Histidine & 78 Lysine & 78 Lysine & \\
\hline & 77 Lysine & 79 Lysine & 79 Lysine & \\
\hline $\begin{array}{l}\text { Total number of post-translational } \\
\text { modification sites }\end{array}$ & 35 & 45 & 40 & 25 \\
\hline
\end{tabular}

HNE = 4-hydroxynonenal.

American Meat Science Association. 
Table 5. Differential $\mathrm{PTM}^{\ddagger}$ identified in myoglobin isolated from non-aged ${ }^{1}$ and aged $^{2}$ beef longissimus lumborum muscle

\begin{tabular}{|c|c|c|c|c|c|}
\hline \multicolumn{3}{|c|}{ Non-aged beef } & \multicolumn{3}{|c|}{ Aged beef } \\
\hline Position ${ }^{\dagger}$ & Residue & Modification & Position & Residue & Modification \\
\hline & & & 31 & Arginine & $\mathbf{M}^{*}$ \\
\hline 34 & Threonine & $\mathrm{P}$ & 34 & Threonine & $\mathrm{P}$ \\
\hline 42 & Lysine & $\mathrm{M}$ & 42 & Lysine & M \\
\hline 45 & Lysine & $\mathbf{H}^{\Psi}$ & & & \\
\hline 47 & Lysine & $\mathbf{H}^{\Psi}$ & & & \\
\hline \multirow[t]{2}{*}{50} & Lysine & A & 50 & Lysine & A \\
\hline & & & 51 & Threonine & $\mathbf{P}^{*}$ \\
\hline 56 & Lysine & M H & 56 & Lysine & $\mathbf{A}^{*} M \mathbf{C}^{*} \mathrm{H}$ \\
\hline 58 & Serine & $\mathrm{P}$ & 58 & Serine & $\mathrm{P}$ \\
\hline 62 & Lysine & $\mathrm{M} \mathrm{C} \mathrm{H}$ & 62 & Lysine & $\mathrm{M} \mathrm{C} \mathrm{H}$ \\
\hline 63 & Lysine & $\mathrm{M} \mathrm{A} \mathrm{C} \mathrm{H}$ & 63 & Lysine & $\mathrm{M} \mathrm{A} \mathrm{C} \mathrm{H}$ \\
\hline 64 & Histidine & $\mathrm{H}$ & 64 & Histidine & $\mathrm{H}$ \\
\hline 67 & Threonine & $\mathrm{P}$ & 67 & Threonine & $\mathrm{P}$ \\
\hline 70 & Threonine & $\mathrm{P}$ & 70 & Threonine & $\mathrm{P}$ \\
\hline 77 & Lysine & $\mathrm{ACH}$ & 77 & Lysine & A $\mathbf{M}^{*} \mathrm{C} H$ \\
\hline 78 & Lysine & $\mathrm{AC}$ & 78 & Lysine & A $\mathbf{M}^{*} \mathrm{C} \mathbf{H}^{*}$ \\
\hline 79 & Lysine & $\mathrm{A} \mathbf{C}^{\Psi}$ & 79 & Lysine & A $\mathbf{M}^{*} \mathbf{H}^{*}$ \\
\hline \multirow[t]{3}{*}{87} & Lysine & $\mathbf{A}^{\Psi} \mathbf{C}^{\Psi}$ & & & \\
\hline & & & 96 & Lysine & $\mathbf{M}^{*} \mathbf{C}^{*}$ \\
\hline & & & 98 & Lysine & $\mathbf{M}^{*} \mathbf{C}^{*}$ \\
\hline 102 & Lysine & $\mathrm{C}$ & 102 & Lysine & $\mathbf{M}^{*} \mathrm{C}$ \\
\hline 103 & Tyrosine & $\mathrm{P}$ & 103 & Tyrosine & $\mathrm{P}$ \\
\hline 108 & Serine & $\mathrm{P}$ & 108 & Serine & $\mathrm{P}$ \\
\hline \multirow[t]{2}{*}{118} & Lysine & $\mathbf{A}^{\Psi} \mathrm{M}$ & 118 & Lysine & M C \\
\hline & & & 121 & Serine & $\mathbf{P}^{*}$ \\
\hline 132 & Serine & $\mathrm{P}$ & 132 & Serine & $\mathrm{P}$ \\
\hline \multirow[t]{3}{*}{133} & Lysine & $\mathrm{A} \mathrm{C}$ & 133 & Lysine & A $\mathbf{M}^{*} \mathrm{C}$ \\
\hline & & & 139 & Arginine & $\mathbf{M}^{*}$ \\
\hline & & & 147 & Lysine & $\mathbf{A}^{*} \mathbf{C}^{*}$ \\
\hline Total & 22 & 35 & Total & 26 & 49 \\
\hline
\end{tabular}

${ }^{\star}$ Differential PTM and their locations are listed in boldface.

${ }^{1}$ Non-aged $=$ aged for $0 \mathrm{~d}$.

${ }^{2} \mathrm{Aged}=$ aged in vacuum packaging at $2{ }^{\circ} \mathrm{C}$ for 7,14 , or $21 \mathrm{~d}$.

${ }^{\dagger}$ Amino acid positions in the sequence of myoglobin from both non-aged and aged beef are placed in the same row for direct comparison.

*PTM unique to myoglobin isolated from beef longissimus lumborum muscle aged in vacuum packaging at $2^{\circ} \mathrm{C}$ for 7,14 , or $21 \mathrm{~d}$.

${ }^{\Psi} \mathrm{PTM}$ unique to myoglobin isolated from non-aged beef longissimus lumborum muscle.

A = Acetylation; $\quad \mathrm{C}=$ Carboxymethylation; $\quad \mathrm{H}=$ 4-hydroxynonenal alkylation; $\mathrm{M}=$ Methylation; $\mathrm{P}=$ Phosphorylation; $\mathrm{PTM}=$ post-translational modification.

modified by HNE. Viana et al. (2020) observed the number of HNE adduction sites increased with storage, with 6 histidines (positions 24, 36, 64, 93, 113, and 152) adducted after $21 \mathrm{~d}$ of incubation at $\mathrm{pH} 5.6$ and $4^{\circ} \mathrm{C}$; however, in the current study, only $1 \mathrm{HNE}$ alkylation site (K77) was detected after $21 \mathrm{~d}$ of aging. The lower number of $\mathrm{HNE}$ alkylation sites observed in situ in beef $\mathrm{Mb}$ in the present study than in vitro (Suman et al., 2006; Viana et al., 2020) could be possibly due to (1) HNE adducting to several proteins other than $\mathrm{Mb}$ in muscle food matrix or (2) the formation of other in situ PTM in $\mathrm{Mb}$ adversely influencing $\mathrm{HNE}$ alkylation.

Overall, greater numbers of PTM were identified in $\mathrm{Mb}$ from aged beef than in $\mathrm{Mb}$ from non-aged counterparts (Table 5). These aging-induced PTM, especially those occurring close to hydrophobic heme pocket, could disrupt $\mathrm{Mb}$ tertiary structure, heme affinity, and oxygen binding capacity, leading to the decreased color stability in aged beef observed in the present study. Furthermore, PTM at K45, K47, and K87 were unique to $\mathrm{Mb}$ from non-aged beef, whereas PTM at R31, T51, K96, K98, S121, R139, and K147 were unique to $\mathrm{Mb}$ from aged counterparts (Table 5), indicating that these Mb PTM sites could be used as biomarkers for fresh beef color stability.

\section{Conclusions}

$\mathrm{Mb}$ in fresh beef LL muscle underwent PTM (phosphorylation, methylation, carboxymethylation, acetylation, and HNE alkylation) during postmortem aging. Increased numbers of phosphorylation, methylation and carboxymethylation sites were detected in $\mathrm{Mb}$ from aged beef compared with $\mathrm{Mb}$ from non-aged counterparts, whereas acetylation sites decreased during aging. While the number of HNE alkylation sites remained the same during $14 \mathrm{~d}$ of aging, HNE adduction at K78 and K79 were unique to aged beef, indicating that HNE alkylation of lysine residues might play a critical role in $\mathrm{Mb}$ redox stability. The aging-induced PTM could compromise $\mathrm{Mb}$ redox stability by adding modifying groups to amino acids-especially those close to the hydrophobic heme pocket-and thus accelerate $\mathrm{Mb}$ oxidation and beef discoloration. These in situ $\mathrm{Mb}$ PTM could be utilized as novel biomarkers for fresh beef color stability.

\section{Acknowledgments}

This project was supported by the Agriculture and Food Research Initiative Grant 2016-67018-24614 from the USDA National Institute of Food and Agriculture.

\section{Literature Cited}

Abu-Farha, M., S. Lanouette, F. Elisma, V. Tremblay, J. Butson, D. Figeys, and J. F. Couture. 2011. Proteomic analyses of the SMYD family interactomes identify HSP90 as a novel target 
for SMYD2. J. Mol. Cell Biol. 3:301-308. https://doi.org/10. 1093/jmcb/mjr025.

Aggarwal, S., S. K. Banerjee, N. C. Talukdar, and A. K. Yadav. 2020. Post-translational modification crosstalk and hotspots in sirtuin interactors implicated in cardiovascular diseases. Frontiers in Genetics. 11:356. https://doi.org/10.3389/fgene. 2020.00356 .

Alderton, A. L., C. Faustman, D. C. Liebler, and D. W. Hill. 2003. Induction of redox instability of bovine myoglobin by adduction with 4-hydroxy-2-nonenal. Biochemistry-US. 42:43984405. https://doi.org/10.1021/bi0271695.

Ali, I., R. J. Conrad, E. Verdin, and M. Ott. 2018. Lysine acetylation goes global: From epigenetics to metabolism and therapeutics. Chem. Rev. 118:1216-1252. https://doi.org/10.1021/acs. chemrev.7b00181.

American Meat Science Association. 2012. Meat color measurement guidelines. 2nd edition. Am. Meat Sci. Assoc., Champaign, IL.

Anderson, M. J., S. M. Lonergan, and E. Huff-Lonergan. 2014. Differences in phosphorylation of phosphoglucomutase 1 in beef steaks from the longissimus dorsi with high or low star probe values. Meat Sci. 96:379-384. https://doi.org/10. 1016/j.meatsci.2013.07.017.

Ardito, F., M. Giuliani, D. Perrone, G. Troiano, and L. Lo Muzio. 2017. The crucial role of protein phosphorylation in cell signaling and its use as targeted therapy. Int. J. Mol. Med. 40:271-280. https://doi.org/10.3892/ijmm.2017.3036.

Azami-Movahed, M., A. A. Meratan, A. Ghasemi, A. EbrahimHabibi, and M. Nemat-Gorgani. 2018. Acetylation of lysine residues in apomyoglobin: Structural changes, amyloid fibrillation, and role of surface charge. Int. J. Biol. Macromol. 107:626-634. https://doi.org/10.1016/j.ijbiomac. 2017.09.040.

Banaszak, L. J., P. A. Andrews, J. W. Burgner, E. H. Eylar, and F. R. Gurd. 1963. Carboxymethylation of sperm whale metmyoglobin. J. Biol. Chem. 238:3307-3314.

Bekhit, A. E. D., G. H. Geesink, J. D. Morton, and R. Bickerstaffe. 2001. Metmyoglobin reducing activity and colour stability of ovine longissimus muscle. Meat Sci. 57:427-435. https://doi. org/10.1016/S0309-1740(00)00121-2.

Bostelaar, T., V. Vitvitsky, J. Kumutima, B. E. Lewis, P. K. Yadav, T. C. Brunold, M. Filipovic, N. Lehnert, T. L. Stemmler, and R. Banerjee. 2016. Hydrogen sulfide oxidation by myoglobin. J. Am. Chem. Soc. 138:8476-8488. https://doi.org/10.1021/ jacs.6b03456.

Bradford, M. M. 1976. A rapid and sensitive method for the quantitation of microgram quantities of protein utilizing the principle of protein-dye binding. Anal. Biochem. 72:248-254. https://doi.org/10.1016/0003-2697(76)90527-3.

Bremang, M., A. Cuomo, A. M. Agresta, M. Stugiewicz, M. Spadotto, and M. Bonaldi. 2013. Mass spectrometry-based identification and characterisation of lysine and arginine methylation in the human proteome. Mol. Biosyst. 9:22312247. https://doi.org/10.1039/C3MB00009E.

Cameron, A. D., S. J. Smerdon, A. J. Wilkinson, J. Habash, J. R. Helliwell, T. Li, and J. S. Olson. 1993. Distal pocket polarity in ligand binding to myoglobin: Deoxy and carbonmonoxy forms of a threonine68 (E11) mutant investigated by X-ray crystallography and infrared spectroscopy. BiochemistryUS. 32:13061-13070. https://doi.org/10.1021/bi00211a016.

Canto, A. C. V. C. S., B. R. C. Costa-Lima, S. P. Suman, M. L. G. Monteiro, F. M. Viana, A. P. A. A. Salim, M. N. Nair, T. J. P. Silva, and C. A. Conte-Junior. 2016. Color attributes and oxidative stability of longissimus lumborum and psoas major muscles from Nellore bulls. Meat Sci. 121:19-26. http://dx. doi.org/10.1016/j.meatsci.2016.05.015.

Canto, A. C. V. C. S., S. P. Suman, M. N. Nair, S. Li, G. Rentfrow, C. M. Beach, T. J. P. Silva, T. L. Wheeler, S. D. Shackelford, A. Grayson, R. O. McKeith, and D. A. King. 2015. Differential abundance of sarcoplasmic proteome explains animal effect on beef Longissimus lumborum color stability. Meat Sci. 102:90 98. http://dx.doi.org/10.1016/j.meatsci.2014.11.011.

Carlson, K. B., K. J. Prusa, C. A. Fedler, E. M. Steadham, E. HuffLonergan, and S. M. Lonergan. 2017. Proteomic features linked to tenderness of aged pork loins. J. Anim. Sci. 95: 2533-2546. https://doi.org/10.2527/jas.2016.1122.

Chen, H. J. C., S. W. Ip, and F. D. Lin. 2017. Simultaneous mass spectrometric analysis of methylated and ethylated peptides in human hemoglobin: Correlation with cigarette smoking. Chem. Res. Toxicol. 30:2074-2083. https://doi.org/10.1021/ acs.chemrestox. $7 \mathrm{~b} 00234$.

CIE. 1976. Official recommendations on uniform colour space, colour difference equations and metric colour terms. Publication no. 15 (E-1.3.1), suppl. 2. Commission Internationale de l'Eclairage, Paris, France.

Clarke, S. G. 2018. The ribosome: A hot spot for the identification of new types of protein methyltransferases. J. Biol. Chem. 293:10438-10446. https://doi.org/10.1074/jbc.AW118. 003235 .

Codreanu, S. G., J. C. Ullery, J. Zhu, K. A. Tallman, W. N. Beavers, N. A. Porter, L. J. Marnett, B. Zhang, and D. C. Liebler. 2014. Alkylation damage by lipid electrophiles targets functional protein systems. Mol. Cell. Proteomics. 13:849-859. https://doi.org/10.1074/mcp.M113.032953.

Colle, M. J., R. P. Richard, K. M. Killinger, J. C. Bohlscheid, A. R. Gray, W. I. Loucks, R. N. Day, A. S. Cochran, J. A. Nasados, and M. E. Doumit. 2015. Influence of extended aging on beef quality characteristics and sensory perception of steaks from the gluteus medius and longissimus lumborum. Meat Sci. 110:32-39. https://doi.org/10.1016/j.meatsci.2015.06.013.

Cruzen, S. M., S. C. Pearce, L. H. Baumgard, N. K. Gabler, E. HuffLonergan, and S. M. Lonergan. 2015. Proteomic changes to the sarcoplasmic fraction of predominantly red or white muscle following acute heat stress. J. Proteomics. 128:141153. https://doi.org/10.1016/j.jprot.2015.07.032.

Curtiss, L. K., and J. L. Witztum. 1985. Plasma apolipoproteins AI, AII, B, CI, and E are glucosylated in hyperglycemic diabetic subjects. Diabetes. 34:452-461. https://doi.org/10.2337/diab. 34.5.452.

Decker, E. A., S. A. Livisay, and S. Zhou. 2000. Mechanisms of endogenous skeletal muscle antioxidants: Chemical and physical aspects. In: E. A. Decker, C. Faustman, and C. J. Lopez-Bote, Editors,Antioxidants in muscle foods: Nutritional strategies to improve quality. Wiley Interscience, New York. pp. 25-60.

Diliberto D. J.Jr., O. H. Veiveros, and J. Axelrod. 1976. Subcellular distribution of protein carboxymethylase and its endogenous 
substrates in the adrenalmedulla: Possible role in excitationsecretion coupling. P. Natl. Acad. Sci. USA. 73:4050-4054. https://doi.org/10.1073/pnas.73.11.4050.

Du, M., X. Li, Z. Li, Q. Shen, C. Ren, and D. Zhang. 2019. Calpastatin inhibits the activity of phosphorylated $\mu$-calpain in vitro. Food Chem. 274:743-749. https://doi.org/10.1016/ j.foodchem.2018.09.073.

Elroy, N. N., J. Rogers, G. G. Mafi, D. L. VanOverbeke, S. D. Hartson, and R. Ramanathan. 2015. Species-specific effects on non-enzymatic metmyoglobin reduction in vitro. Meat Sci. 105:108-113. http://dx.doi.org/10.1016/j.meatsci.2015. 03.010 .

English, A. R., G. G. Mafi, D. L. VanOverbeke, and R. Ramanathan. 2016. Effects of extended aging and modified atmospheric packaging on beef top loin steak color. J. Anim. Sci. 94:1727-1737. https://doi.org/10.2527/jas.20150149 .

Esterbauer, H., R. J. Schaur, and H. Zollner. 1991. Chemistry and biochemistry of 4-hydroxynonenal, malonaldehyde and related aldehydes. Free Radical Bio. Med. 11:81-128. https://doi.org/10.1016/0891-5849(91)90192-6.

Fang, C. Y., H. Y. Chen, M. Wang, P. L. Chen, C. F. Chang, L. S. Chen, C. H. Shen, W. C. Ou, M. D. Tsai, P. H. Hsu, and D. Chang. 2010. Global analysis of modifications of the human BK virus structural proteins by LC-MS/MS. Virology. 402:164-176. https://doi.org/10.1016/j.virol.2010.03.029.

Farouk, M. M., M. Beggan, S. Hurst, A. Stuart, P. M. Dobbie, and A. E. D. Bekhit. 2007. Meat quality attributes of chilled venison and beef. J. Food Quality. 30:1023-1039. https://doi.org/ 10.1111/j.1745-4557.2007.00175.x.

Faustman, C., and R. G. Cassens. 1990. The biochemical basis for discoloration in fresh meat: A review. J. Muscle Foods. 1:217-243. https://doi.org/10.1111/j.1745-4573.1990. tb00366.x.

Faustman, C., and A. Phillips. 2001. Measurement of discoloration in fresh meat. In: R. E. Wrolstad, editor, Current protocols in food analytical chemistry. Wiley and Sons, New York, NY. p. F3.3.1-F3.3.13. https://doi.org/10.1002/0471142913. faf0303s 00 .

Faustman, C., D. C. Liebler, T. D. McClure, and Q. R. Sun. 1999. $\alpha$, $\beta$-Unsaturated aldehydes accelerate oxymyoglobin oxidation. J. Agr. Food Chem. 47:3140-3144. https://doi.org/10.1021/ jf990016c.

Faustman, C., Q. Sun, R. Mancini, and S. P. Suman. 2010. Myoglobin and lipid oxidation interactions: Mechanistic bases and control. Meat Sci. 86:86-94. https://doi.org/10. 1016/j.meatsci.2010.04.025.

Fox, J. B. 1966. Chemistry of meat pigments. J. Agr. Food Chem. 14:207-210. https://doi.org/10.1021/jf60145a003.

Giddings, G. G. 1977. The basis of color in muscle foods. J. Food Sci. 42:288-294. https://doi.org/10.1111/j.1365-2621.1977. tb01484.x.

Graves, J. D., and E. G. Krebs. 1999. Protein phosphorylation and signal transduction. Pharmacol. Therapeut. 82:111-121. https://doi.org/10.1016/S0163-7258(98)00056-4.

Greer, E. L., and Y. Shi. 2012. Histone methylation: a dynamic mark in health, disease and inheritance. Nat. Rev. Genet. 13:343-357. https://doi.org/10.1038/nrg3173.
Grunwald, E. W., and M. P. Richards. 2006. Studies with myoglobin variants indicate that released hemin is the primary promoter of lipid oxidation in washed fish muscle. J. Agr. Food Chem. 54:4452-4460. https://doi.org/10.1021/ jf0603228.

Hackett, S. F., and P. A. Campochiaro. 1988. Implication of protein carboxymethylationin retinal pigment epithelial cell chemotaxis. Ophthalmic Res. 20:54-59. https://doi.org/10.1159/ 000266255.

Halligan, B. D., V. Ruotti, W. Jin, S. Laffoon, S. N. Twigger, and E. A. Dratz. 2004. ProMoST (Protein Modification Screening Tool): A web-based tool for mapping protein modifications on two-dimensional gels. Nucleic Acids Res. 32:W638W644. https://doi.org/10.1093/nar/gkh356.

Han, K. K., and A. Martinage. 1992. Post-translational chemical modification(s) of proteins. Int. J. Biochem. 24:19-28. https://doi.org/10.1016/0020-711X(92)90225-P.

Hargrove, M. S., A. J. Wilkinson, and J. S. Olson. 1996. Structural factors governing hemin dissociation from metmyoglobin. Biochemistry-US. 35:11300-11309. https://doi.org/10.1021/ bi960372d.

Harris, C. M., and R. L. Hill. 1969. The carboxymethylation of human metmyoglobin. J. Biol. Chem. 244:2195-2203.

Hohenester, U. M., K. Ludwig, and S. Konig. 2013. Chemical phosphorylation of histidine residues in proteins using potassium phosphoramidate- a tool for the analysis of acid-labile phosphorylation. Curr. Drug Deliv. 10:58-63. https://doi. org/10.2174/1567201811310010010.

Hojlund, K., B. P. Bowen, H. Hwang, C. R. Flynn, L. Madireddy, T. Geetha, P. Langlais, C. Meyer, L. J. Mandarino, and Z. Yi. 2009. In vivo phosphoproteome of human skeletal muscle revealed by phosphopeptide enrichment and HPLC- ESIMS/MS. J. Proteome Res. 8:4954-4965. https://doi.org/10. 1021/pr9007267.

Huang, J., and S. L. Berger. 2008. The emerging field of dynamic lysine methylation of non-histone proteins. Curr. Opin. Genet. Dev. 18:152-158. https://doi.org/10.1016/j.gde.2008.01.012.

Huang, H., M. R. Larsen, A. H. Karlsson, L. Pomponio, L. N. Costa, and R. Lametsch. 2011. Gel-based phosphoproteomics analysis of sarcoplasmic proteins in postmortem porcine muscle with $\mathrm{pH}$ decline rate and time differences. Proteomics. 11:4063-4076. https://doi.org/10.1002/pmic. 201100173.

Huang, H., M. R. Larsen, and R. Lametsch. 2012. Changes in phosphorylation of myofibrillar proteins during postmortem development of porcine muscle. Food Chem. 134:1999-2006. https://doi.org/10.1016/j.foodchem.2012.03.132.

Huang, H., T. L. Scheffler, D. E. Gerrard, M. R. Larsen, and R. Lametsch. 2018. Quantitative proteomics and phosphoproteomics analysis revealed different regulatory mechanisms of Halothane and Rendement Napole genes in porcine muscle metabolism. J. Proteome Res. 17:2834-2849. https://doi. org/10.1021/acs.jproteome.8b00294.

Hugli, T. E., and F. R. Gurd. 1970. Carboxymethylation of sperm whale myoglobin in the crystalline state. J. Biol. Chem. 245:1930-1938.

Hunter, T. 2000. Signaling-2000 and beyond. Cell. 100:113-127. https://doi.org/10.1016/s0092-8674(00)81688-8. 
Hunter, T. 2012. Why nature chose phosphate to modify proteins. Philos. T. R. Soc. B. 367:2513-2516. https://doi.org/10.1098/ rstb.2012.0013.

Imazaki, P. H., C. Douny, M. Elansary, M. L. Scippo, and A. Clinquart. 2018. Effect of muscle type, aging technique, and aging time on oxidative stability and antioxidant capacity of beef packed in high-oxygen atmosphere. J. Food Process. Pres. 42:e13603. https://doi.org/10.1111/jfpp.13603.

Isom, A. L., S. Barnes, L. Wilson, M. Kirk, L. Coward, and V. Darley-Usmar. 2004. Modification of Cytochrome c by 4hydroxy-2-nonenal: Evidence for histidine, lysine, and arginine-aldehyde adducts. J. Am. Soc. Mass Spectr. 15:11361147. https://doi.org/10.1016/j.jasms.2004.03.013.

Jayasooriya, S. D., P. J. Torley, B. R. D'arcy, and B. R. Bhandari. 2007. Effect of high power ultrasound and ageing on the physical properties of bovine Semitendinosus and Longissimus muscles. Meat Sci. 75:628-639. https://doi. org/10.1016/j.meatsci.2006.09.010.

Jensen, O. N., 2004. Modification-specific proteomics: Characterization of post-translational modifications by mass spectrometry. Curr. Opin. Chem. Biol. 8:33-41. https://doi. org/10.1016/j.cbpa.2003.12.009.

Jeong, J. Y., S. J. Hur, H. S. Yang, S. H. Moon, Y. H. Hwang, G. B. Park, and S. T. Joo. 2009. Discoloration characteristics of 3 major muscles from cattle during cold storage. J. Food Sci. 74:C1-C5. https://doi.org/10.1111/j.1750-3841.2008. 00983.x.

Jiang, S., Y. Liu, Z. Shen, B. Zhou, and Q. W. Shen. 2019. Acetylome profiling reveals extensive involvement of lysine acetylation in the conversion of muscle to meat. J. Proteomics. 205:103412. https://doi.org/10.1016/j.jprot.2019.103412.

Joseph, P., S. P. Suman, G. Rentfrow, S. Li, and C. M. Beach. 2012. Proteomics of muscle-specific beef color stability. J. Agr. Food Chem. 60:3196-3203. https://doi.org/10.1021/ jf204188v.

Kamelgarn, M., J. Chen, L. Kuang, H. Jin, E. J. Kasarskis, and H. Zhu. 2018. ALS mutations of FUS suppress protein translation and disrupt the regulation of nonsense-mediated decay. P. Natl. Acad. Sci. USA. 115:E11904-E11913. https://doi. org/10.1073/pnas.1810413115.

King, D. A., S. D. Shackelford, N. Kalchayanand, and T. L. Wheeler. 2012. Sampling and aging effects on beef longissimus color stability measurements. J. Anim. Sci. 90:35963605. https://doi.org/10.2527/jas.2011-4871.

King, D. A., S. D. Shackelford, and T. L. Wheeler. 2011. Relative contributions of animal and muscle effects to variation in beef lean color stability. J. Anim. Sci. 89:1434-1451. https://doi. org/10.2527/jas.2010-3595.

Kitahara, Y., A. Matsuoka, N. Kobayashi, and K. Shikama. 1990. Autoxidation of myoglobin from bigeye tuna fish (Thunnus obesus). BBA-Protein Struct. M. 1038:23-28. https://doi. org/10.1016/0167-4838(90)90005-Z.

Krueger, K. E., and S. Srivastava. 2006. Posttranslational protein modifications: Current implications for cancer detection, prevention, and therapeutics. Mol. Cell. Proteomics. 5:17991810. https://doi.org/10.1074/mcp.R600009-MCP200.

Kumar, Y., A. Khachane, M. Belwal, S. Das, K. Somsundaram, and U. Tatu. 2004. ProteoMod: A new tool to quantitate protein post-translational modifications. Proteomics. 4:1672-1683. https://doi.org/10.1002/pmic.200300778.

Kung, S. D. 1976. Isoelectric points of the polypeptide components of tobacco fraction 1 protein. Bot. Bull. Acad. Sinica. 17:185191.

Kwan, S. H., S. Baie, and M. Nazri Ismail. 2016. Profiling of proteins and post translational modifications of Channa striatus dried meat. Curr. Proteomics. 13:9-19. https://doi.org/10. 2174/1570164613666160413123846.

Lametsch, R., M. R. Larsen, B. Essen-Gustavsson, M. JensenWaern, K. Lundstrom, and G. Lindahl. 2011. Postmortem changes in pork muscle protein phosphorylation in relation to the RN genotype. J. Agr. Food Chem. 59:11608-11615. https://doi.org/10.1021/jf201936h.

Lanouette, S., V. Mongeon, D. Figeys, and J. F. Couture. 2014. The functional diversity of protein lysine methylation. Mol. Syst. Biol. 10:724. https://doi.org/10.1002/msb.134974.

Lawrie, R. A. 1998. Meat Science. 6th edition. Woodhead Publishing Ltd., Cambridge England.

Ledward, D. A. 1985. Post-slaughter influences on the formation of metmyoglobin in beef muscles. Meat Sci. 15:149-171. https:// doi.org/10.1016/0309-1740(85)90034-8.

Lee, S., A. L. Phillips, D. C. Liebler, and C. Faustman. 2003. Porcine oxymyoglobin and lipid oxidation in vitro. Meat Sci. 63:241-247. https://doi.org/10.1016/s0309-1740(02) 00076-1.

Li, X., L. Chen, F. He, M. Li, Q. Shen, and D. Zhang. 2017. A comparative analysis of phosphoproteome in ovine muscle at early postmortem in relationship to tenderness. J. Sci. Food Agr. 97:4571-4579. https://doi.org/10.1002/jsfa.8326.

Li, M., Z. Li, X. Li, J. Xin, Y. Wang, G. Li, L. Wu, Q. W. Shen, and D. Zhang. 2018a. Comparative profiling of sarcoplasmic phosphoproteins in ovine muscle with different color stability. Food Chem. 240:104-111. http://dx.doi.org/10.1016/j. foodchem.2017.07.097.

Li, Z., M. Li, X. Li, J. Xin, Y. Wang, Q. W. Shen, and D. Zhang. 2018b. Quantitative phosphoproteomic analysis among muscles of different color stability using tandem mass tag labeling. Food Chem. 249:8-15. https://doi.org/10.1016/j. foodchem.2017.12.047.

Li, M., H. Ogilvie, J. Ochala, K. Artemenko, H. Iwamoto, N. Yagi, J. Bergquist, and L. Larsson. 2015. Aberrant post-translational modifications compromise human myosin motor function in old age. Aging Cell, 14:228-235. https://doi.org/10.1111/ acel. 12307

Li, X., D. Zhang, C. Ren, Y. Bai, M. Ijaz, C. Hou, and L. Chen. 2021. Effects of protein posttranslational modifications on meat quality: A review. Compr. Rev. Food Sci. F. 20:289331. https://doi.org/10.1111/1541-4337.12668.

Lin, Y. W. 2018. Structure and function of heme proteins regulated by diverse post-translational modifications. Arch. Biochem. Biophys. 641:1-30. https://doi.org/10.1016/j.abb.2018.01.009.

Lindahl, G. 2011. Colour stability of steaks from large beef cuts aged under vacuum or high oxygen modified atmosphere. Meat Sci. 87:428-435. https://doi.org/10.1016/j.meatsci. 2010.10 .023$.

Lindsay, A., J. Healy, W. Mills, J. Lewis, N. Gill, N. Draper, and S. P. Gieseg. 2016. Impact-induced muscle damage and urinary 
pterins in professional rugby: 7, 8-dihydroneopterin oxidation by myoglobin. Scand. J. Med. Sci. Spor. 26:329-337. https:// doi.org/10.1111/sms.12436.

Liu, R., Q. Fu, S. Lonergan, E. Huff-Lonergan, L. Xing, L. Zhang, Y. Bai, G. Zhou, and W. Zhang. 2018. Identification of S-nitrosylated proteins in postmortem pork muscle using modified biotin switch method coupled with isobaric tags. Meat Sci. 145:431-439. https://doi.org/10.1016/j.meatsci. 2018.07.027.

Liu, R., Y. Li, M. Wang, G. Zhou, and W. Zhang. 2016. Effect of protein S-nitrosylation on autolysis and catalytic ability of $\mu$-calpain. Food Chem. 213:470-477. https://doi.org/10. 1016/j.foodchem.2016.06.104.

Liu, Q., K. K. Scheller, S. C. Arp, D. M. Schaefer, and S. N. Williams. 1996. Titration of fresh meat color stability and malondialdehyde development with Holstein steers fed vitamin E supplemented diets. J. Anim. Sci. 74:117-126. https://doi.org/10.2527/1996.741117x.

Livingston, D. J., and W. D. Brown. 1981. The chemistry of myoglobin and its reactions. Food Technol.-Chicago. 35:244-252.

Livingston, D. J., S. J. McLachlan, G. N. La Mar, and W. D. Brown. 1985. Myoglobin: Cytochrome b5 interactions and the kinetic mechanism of metmyoglobin reductase. J. Biol. Chem. 260:15699-15707.

Livingston, D. J., D. A. Watts, and W. D. Brown. 1986. Myoglobin interspecies structural differences: Effects on autoxidation and oxygenation. Arch. Biochem. Biophys. 249:106-115. https:// doi.org/10.1016/0003-9861(86)90565-5.

Lodish, H. F. 1981. Post-translational modification of proteins. Enzyme Microb. Tech. 3:178-188. https://doi.org/10.1016/ 0141-0229(81)90084-3.

Luo, M., 2018. Chemical and biochemical perspectives of protein lysine methylation. Chem. Rev. 118:6656-6705. https://doi. org/10.1021/acs.chemrev.8b00008.

Mancini, R. A., and M. C. Hunt. 2005. Current research in meat color. Meat Sci. 71:100-121. https://doi.org/10.1016/j. meatsci.2005.03.003.

Mancini, R. A., and R. Ramanathan. 2014. Effects of postmortem storage time on color and mitochondria in beef. Meat Sci. 98:65-70. https://doi.org/10.1016/j.meatsci.2014.04.007.

Mancini, R. A., S. P. Suman, M. K. R. Konda, and R. Ramanathan. 2009. Effect of carbon monoxide packaging and lactateenhancement on the color stability of beef steaks stored at $1{ }^{\circ} \mathrm{C}$ for 9 days. Meat Sci. 81:71-76. https://doi.org/10. 1016/j.meatsci.2008.06.021.

Mann, M., and O. N. Jensen. 2003. Proteomic analysis of posttranslational modifications. Nat. Biotechnol. 21:255-261. https://doi.org/10.1038/nbt0303-255.

Marino, R., M. Albenzio, A. della Malva, M. Caroprese, A. Santillo, and A. Sevi. 2014. Changes in meat quality traits and sarcoplasmic proteins during aging in three different cattle breeds. Meat Sci. 98:178-186. https://doi.org/10.1016/j. meatsci.2014.05.024.

McKenna, D. R., P. D. Mies, B. E. Baird, K. D. Pfeiffer, J. W. Ellebracht, and J. W. Savell. 2005. Biochemical and physical factors affecting discoloration characteristics of 19 bovine muscles. Meat Sci. 70:665-682. https://doi.org/10.1016/j. meatsci.2005.02.016.
McLachlin, D. T., and B. T. Chait. 2001. Analysis of phosphorylated proteins and peptides by mass spectrometry. Curr. Opin. Chem. Biol. 5:591-602. https://doi.org/10.1016/S1367-5931 (00)00250-7.

Min, B., and D. U. Ahn. 2005. Mechanism of lipid peroxidation in meat and meat products - A review. Food Sci. Biotechnol. 14:152-163.

Mitacek, R. M., Y. Ke, J. E. Prenni, R. Jadeja, D. L. VanOverbeke, G. G. Mafi, and R. Ramanathan. 2019. Mitochondrial degeneration, depletion of $\mathrm{NADH}$, and oxidative stress decrease color stability of wet-aged beef longissimus steaks. J. Food Sci. 84:38-50. https://doi.org/10.1111/1750-3841. 14396.

Moore, K. E., and O. Gozani. 2014. An unexpected journey: Lysine methylation across the proteome. BBA-Gene Regul. Mech. 1839:1395-1403. https://doi.org/10.1016/j.bbagrm.2014.02. 008.

Müller, M. M. 2017. Post-translational modifications of protein backbones: Unique functions, mechanisms, and challenges. Biochemistry-US. 57:177-185. https://doi.org/10.1021/acs. biochem.7b00861.

Nair, M. N., S. Li, C. M. Beach, G. Rentfrow, and S. P. Suman. 2018a. Changes in the sarcoplasmic proteome of beef muscles with differential color stability during postmortem aging. Meat Muscle Biol. 2:1-17. https://doi.org/10.22175/ mmb2017.07.0037.

Nair, M. N., S. Li, C. M. Beach, G. Rentfrow, and S. P. Suman. 2018 b. Intramuscular variations in color and sarcoplasmic proteome of beef during postmortem aging. Meat Muscle Biol. 2:92-101. https://doi.org/10.22175/mmb2017.11.0055.

Nair, M. N., S. P. Suman, S. Li, P. Joseph, and C. M. Beach. 2014. Lipid oxidation-induced oxidation in emu and ostrich myoglobins. Meat Sci. 96:984-993. https://doi.org/10.1016/j. meatsci.2013.08.029.

Naveena, B. M., C. Faustman, N. Tatiyaborworntham, S. Yin, R. Ramanathan, and R. A. Mancini. 2010. Detection of 4hydroxy-2-nonenal adducts of turkey and chicken myoglobins using mass spectrometry. Food Chem. 122:836-840. https:// doi.org/10.1016/j.foodchem.2010.02.062.

Neethling, N. E., S. P. Suman, G. O. Sigge, L. C. Hoffman, and M. C. Hunt. 2017. Exogenous and endogenous factors influencing color of fresh meat from ungulates. Meat Muscle Biol. 1:253-275. https://doi.org/10.22175/mmb2017. 06.0032 .

Nguyen, B. D., Z. Xia, F. Cutruzzola, C. T. Allocatelli, M. Brunori, and G. N. La Mar. 2000. Solution 1H NMR study of the influence of distal hydrogen bonding and $\mathrm{N}$ terminus acetylation on the active site electronic and molecular structure of Aplysia limacine cyanomet myoglobin. J. Biol. Chem. 275:742-751. https://doi.org/10.1074/jbc.275.2.742.

Nigen, A. M., and F. R. Gurd. 1973. Comparison of carboxymethylation patterns of harbor seal and sperm whale myoglobins. J. Biol. Chem. 248:3708-3715.

Obuz, E., L. Akkaya, V. Gok, and M. E. Dikeman. 2014. Effects of blade tenderization, aging method and aging time on meat quality characteristics of Longissimus lumborum steaks from cull Holstein cows. Meat Sci. 96:1227-1232. https://doi.org/ 10.1016/j.meatsci.2013.11.015. 
Ong, S. E., G. Mittler, and M. Mann. 2004. Identifying and quantifying in vivo methylation sites by heavy methyl SILAC. Nat. Methods. 1:119-126. https://doi.org/10.1038/ nmeth715.

Pace, C. N., G. R. Grimsley, and J. M. Scholtz. 2009. Protein ionizable groups: $\mathrm{pK}$ values and their contribution to protein stability and solubility. J. Biol. Chem. 284:13285-13289. https:// doi.org/10.1074/jbc.R800080200.

Pang, C. N. I., E. Gasteiger, and M. R. Wilkins. 2010. Identification of arginine-and lysine-methylation in the proteome of Saccharomyces cerevisiae and its functional implications. BMC Genomics. 11:92. https://doi.org/10.1186/1471-216411-92.

Purchas, R. W., E. C. Triumf, and B. Egelandsdal. 2010. Quality characteristics and composition of the longissimus muscle in the short-loin from male and female farmed red deer in New Zealand. Meat Sci. 86:505-510. https://doi.org/10. 1016/j.meatsci.2010.05.043.

Raghunathan, G., S. Sokalingam, N. Soundrarajan, B. Madan, G. Munussami, and S. G. Lee. 2013. Modulation of protein stability and aggregation properties by surface charge engineering. Mol. Biosyst. 9:2379-2389. https://doi.org/10.1039/ C3MB70068B.

Rakhit, R., R. Navarro, and T. J. Wandless. 2014. Chemical biology strategies for posttranslational control of protein function. Chem. Biol. 21:1238-1252. https://doi.org/10.1016/j. chembiol.2014.08.011.

Ramanathan, R., M. C. Hunt, R. A. Mancini, M. N. Nair, M. L. Denzer, S. P. Suman, and G. G. Mafi. 2020a. Recent updates in meat color research: Integrating traditional and highthroughput approaches. Meat Muscle Biol. 4(2): 7, 1-24. https://doi.org/10.22175/mmb.9598.

Ramanathan, R., and R. A. Mancini. 2018. Role of mitochondria in beef color: A review. Meat Muscle Biol. 2:309-320. https:// doi.org/10.22175/mmb2018.05.0013.

Ramanathan, R., S. P. Suman, and C. Faustman. 2020b. Biomolecular interactions governing fresh meat color in post-mortem skeletal muscle: A review. J. Agr. Food Chem. 68:12779-12787. https://doi.org/10.1021/acs.jafc. 9b08098.

Ray, D. K., and F. R. Gurd. 1967. Some interrelations between carboxymethylation and heme reactions in sperm whale myoglobin. J. Biol. Chem. 242:2062-2068.

Renerre, M. T. 1990. Factors involved in the discoloration of beef meat. Int. J. Food Sci. Tech. 25:613-630. https://doi.org/10. 1111/j.1365-2621.1990.tb01123.x.

Rice, R. H., D. A. Watts, and W. D. Brown. 1979. Sequences of the soluble tryptic peptides from myoglobin of yellowfin tuna (Thunnus albacares). Comp. Biochem. Phys. B. 62:481487. https://doi.org/10.1016/0305-0491(79)90121-4.

Richards, M. P. 2013. Redox reactions of myoglobin. Antioxid. Redox Sign. 18:2342-2351. https://doi.org/10.1089/ars. 2012.4887.

Sammel, L. M., M. C. Hunt, D. H. Kropf, K. A. Hachmeister, and D. E. Johnson. 2002. Comparison of assays for metmyoglobin reducing ability in beef inside and outside semimembranosus muscle. J. Food Sci. 67:978-984. https://doi.org/10.1111/j. 1365-2621.2002.tb09439.x.
Santucci, R., F. Ascoli, G. N. La Mar, R. K. Pandey, and K. M. Smith. 1993. Reconstitution of horse heart myoglobin with hemins methylated at 6-or 7-positions: A circular dichroism study. BBA-Protein Struct. M. 1164:133-137. https://doi. org/10.1016/0167-4838(93)90239-N.

Schlecht, P. 1969. Dielectric properties of hemoglobin and myoglobin II. Dipole moment of sperm whale myoglobin. Biopolymers. 8:757-765. https://doi.org/10.1002/bip.1969. 360080606.

Seideman, S. C., H. R. Cross, G. C. Smith, and P. R. Durland. 1984. Factors associated with fresh meat color: A review. J. Food Quality. 6:211-237. https://doi.org/10.1111/j.1745-4557. 1984.tb00826.x.

Seo, J., and K. J. Lee. 2004. Post-translational modifications and their biological functions: Proteomic analysis and systematic approaches. J. Biochem. Mol. Biol. 37:35-44. https://doi.org/ 10.5483/BMBRep.2004.37.1.035.

Shevchenko, A., H. Tomas, J. Havli, J. V. Olsen, and M. Mann. 2006. In-gel digestion for mass spectrometric characterization of proteins and proteomes. Nat. Protoc. 1:2856-2860. https:// doi.org/10.1038/nprot.2006.468.

Smerdon, S. J., S. Krzywda, A. J. Wilkinson, R. E. Brantley Jr, T. E. Carver, M. S. Hargrove, and J. S. Olson. 1993. Serine92 (F7) contributes to the control of heme reactivity and stability in myoglobin. Biochemistry-US. 32:5132-5138. https://doi. org/10.1021/bi00070a023.

Smith, G. C., K. E. Belk, J. N. Sofos, J. D. Tatum, and S. N. Williams. 2000. Economic implications of improved color stability in beef. In: E. A. Decker, C. Faustman, C. J. Lopez-Bote, Editors, Antioxidants in muscle foods: Nutritional strategies to improve quality. Wiley Interscience, New York. pp. 397-426.

Stewart, J. M., J. A. Blakely, P. A. Karpowicz, E. Kalanxhi, B. J. Thatcher, and B. M. Martin. 2004. Unusually weak oxygen binding, physical properties, partial sequence, autoxidation rate and a potential phosphorylation site of beluga whale (Delphinapterus leucas) myoglobin. Comp. Biochem. Phys. B. 137:401-412. https://doi.org/10.1016/j.cbpc.2004.01.007.

Strange, E. D., R. C. Benedict, J. L. Smith, and L. E. Swift. 1977. Evaluation of rapid tests for monitoring alterations in meat quality during storage. 1. Intact meat. J. Food Protect. 40:843-847. https://doi.org/10.4315/0362-028X-40.12.843.

Strickler, S. S., A. V. Gribenko, A. V. Gribenko, T. R. Keiffer, J. Tomlinson, T. Reihle, V. V. Loladze, and G. I. Makhatadze. 2006. Protein stability and surface electrostatics: A charged relationship. Biochemistry-US. 45:2761-2766. https://doi. org/10.1021/bi0600143.

Suman, S. P., C. Faustman, S. L. Stamer, and D. C. Liebler. 2006. Redox instability induced by 4-hydroxy-2-nonenal in porcine and bovine myoglobins at $\mathrm{pH} 5.6$ and $4{ }^{\circ} \mathrm{C}$. J. Agr. Food Chem. 54:3402-3408. https://doi.org/10.1021/jf052811y.

Suman, S. P., C. Faustman, S. L. Stamer, and D. C. Liebler. 2007. Proteomics of lipid oxidation-induced oxidation of porcine and bovine oxymyoglobins. Proteomics. 7:628-640. https:// doi.org/10.1002/pmic.200600313.

Suman, S. P., M. C. Hunt, M. N. Nair, and G. Rentfrow. 2014. Improving beef color stability: Practical strategies and underlying mechanisms. Meat Sci. 98:490-504. https://doi.org/10. 1016/j.meatsci.2014.06.032. 
Suman, S. P., and P. Joseph. 2013. Myoglobin chemistry and meat color. Annu. Rev. Food Sci. T. 4:79-99. https://doi.org/10. 1146/annurev-food-030212-182623.

Suman, S. P., and M. N. Nair. 2017. Current developments in fundamental and applied aspects of meat color. In: P. P. Purslow, Editor, New aspects of meat quality: From genes to ethics. Elsevier, Oxford, United Kingdom. pp. 115-127.

Szapacs, M. E., J. N. Riggins, L. J. Zimmerman, and D. C. Liebler. 2006. Covalent adduction of human serum albumin by 4hydroxy-2-nonenal: Kinetic analysis of competing alkylation reactions. Biochemistry-US. 45:10521-10528. https://doi. org/10.1021/bi060535q.

Tada, T., Y. Watanabe, A. Matsuoka, M. Ikeda-Saito, K. Imai, Y. Ni-hei, and K. Shikama. 1998. African elephant myoglobin with an unusual previous term autoxidation behavior: Comparison with the H64Q mutant of sperm whale myoglobin. BBA-Protein Struct. M. 1387:165-176. https://doi.org/ 10.1016/S0167-4838(98)00118-6.

Tang, J., C. Faustman, T. A. Hoagland, R. A. Mancini, M. Seyfert, and M. C. Hunt. 2005. Postmortem oxygen consumption by mitochondria and its effects on myoglobin form and stability. J. Agr. Food Chem. 53:1223-1230. https://doi.org/10.1021/ jf048646o.

Tatiyaborworntham, N., C. Faustman, S. Yin, R. Ramanathan, R. A. Mancini, S. P. Suman, C. M. Beach, N. B. Maheswarappa, E. W. Grunwald, and M. P. Richards. 2012. Redox instability and hemin loss of mutant sperm whale myoglobins induced by 4-hydroxynonenal in vitro. J. Agr. Food Chem. 60:8473-8483. https://doi.org/10.1021/ jf301770p.

Uchida, K. 2003. Histidine and lysine as targets of oxidative modification. Amino Acids. 25:249-257. https://doi.org/10.1007/ s00726-003-0015-y.

Uchida, K., and E. R. Stadtman. 1992. Modification of histidine residues in proteins by reaction with 4-hydroxynonenal. P. Natl. Acad. Sci. USA. 89:4544-4548. https://doi.org/10.1073/pnas. 89.10.4544.

Uchida, K., and E. R. Stadtman. 1993. Covalent attachment of 4-hydroxynonenal to glyceraldehyde-3-phosphate dehydrogenase. A possible involvement of intra-and intermolecular cross-linking reaction. J. Biol. Chem. 268:6388-6393.

Ueki, N., and Y. Ochiai. 2004. Primary structure and thermostability of bigeye tuna myoglobin in relation to those of other scombridae fish. Fisheries Sci. 70:875-884. https://doi.org/ 10.1111/j.1444-2906.2004.00882.x.

Ueki, N., and Y. Ochiai. 2006. Effect of amino acid replacements on the structural stability of fish myoglobin. J. Biochem. 140:649-656. https://doi.org/10.1093/jb/mvj192.

Ueki, N., C. J. Chow, and Y. Ochiai. 2005. Characterization of bullet tuna myoglobin with reference to the thermostabilitystructure relationship. J. Agr. Food Chem. 53:4968-4975. https://doi.org/10.1021/jf050261y.

Uhlmann, T., V. L. Geoghegan, B. Thomas, G. Ridlova, D. C. Trudgian, and O. Acuto. 2012. A method for large-scale identification of protein arginine methylation. Mol. Cell
Proteomics. 11:1489-1499. https://doi.org/10.1074/mcp. M112.020743.

van der Laarse, S. A., A. C. Leney, and A. J. Heck. 2018. Crosstalk between phosphorylation and O-Glc NA cylation: Friend or foe. FEBS J. 285:3152-3167. https://doi.org/10.1111/febs. 14491.

Viana, F. M., Y. Wang, S. Li, C. A. Conte-Junior, J. Chen, H. Zhu, and S. P. Suman. 2020.Thermal instability induced by 4-hydroxy-2-nonenal in beef myoglobin. Meat Muscle Biol. 4(1): 18, 1-7. https://doi.org/10.22175/mmb.9479.

Waterhouse, A., M. Bertoni, S. Bienert, G. Studer, G. Tauriello, R. Gumienny, F. T. Heer, T. A. P. de Beer, C. Rempfer, L. Bordoli, and R. Lepore, 2018. SWISS-MODEL: Homology modelling of protein structures and complexes. Nucleic Acids Res. 46:W296-W303. https://doi.org/10.1093/nar/ gky427.

Wood, J. D., M. Enser, A. V. Fisher, G. R. Nute, P. R. Sheard, R. I. Richardson, S. I. Hughes, and F. M. Whittington. 2008. Fat deposition, fatty acid composition and meat quality: A review. Meat Sci. 78:343-358. https://doi.org/10.1016/j.meatsci. 2007.07.019.

Wu, Z., J. Connolly, and K. K. Biggar. 2017. Beyond histones-The expanding roles of protein lysine methylation. FEBS J. 284:2732-2744. https://doi.org/10.1111/febs.14056.

Wu, C. S. C., P. Duffy, and W. D. Brown. 1972. Interaction of myoglobin and cytochrome c. J. Biol. Chem. 247:1899-1903.

Xie, H., S. Bandhakavi, M. R. Roe, and T. J. Griffin. 2007. Preparative peptide isoelectric focusing as a tool for improving the identification of lysine-acetylated peptides from complex mixtures. J. Proteome Res. 6:2019-2026. https://doi.org/ 10.1021/pr060691j.

Yang, J., K. A. Tallman, N. A. Porter, and D. C. Liebler. 2015. Quantitative chemoproteomics for site-specific analysis of protein alkylation by 4-hydroxy-2-nonenal in cells. Anal. Chem. 87:2535-2541. https://doi.org/10.1021/ac504685y.

Yin, M. C., C. Faustman, J. W. Riesen, and S. N. Williams. 1993. $\alpha-$ Tocopherol and ascorbate delay oxymyoglobin and phospholipid oxidation in vitro. J. Food Sci. 58:1273-1276. https:// doi.org/10.1111/j.1365-2621.1993.tb06164.x.

Yin, S., C. Faustman, N. Tatiyaborworntham, R. Ramanathan, N. B. Maheswarappa, R. A. Mancini, P. Joseph, S. P. Suman, and Q. Sun. 2011. Species-specific myoglobin oxidation. J. Agr. Food Chem. 59:12198-12203. https://doi.org/10.1021/ jf202844t.

Zhang, X., Y. Huang, and X. Shi. 2015. Emerging roles of lysine methylation on non-histone proteins. Cell. Mol. Life Sci. 72:4257-4272. https://doi.org/10.1007/s00018-015-2001-4.

Zhao, S., W. Xu, W. Jiang, W. Yu, Y. Lin, T. Zhang, J. Yao, L. Zhou, Y. Zeng, H. Li, and Y. Li. 2010. Regulation of cellular metabolism by protein lysine acetylation. Science. 327:1000 1004. https://doi.org/10.1126/science.1179689.

Zhu, K., J. Zhao, D. M. Lubman, F. R. Miller, and T. J. Barder. 2005. Protein pI shifts due to posttranslational modifications in the separation and characterization of proteins. Anal. Chem. 77:2745-2755. https://doi.org/10.1021/ac048494w. 